\title{
Energy Efficiency of Pacific Northwest Agriculture Irrigation Pumping Systems
}
G. L. Wilfert
B. J. Harrer

March 1987

Prepared for the Bonneville Power Administration under a Related Services Agreement with the U.S. Department of Energy Contract DE-AC06-76RLO 1830

Pacific Northwest Laboratory Operated for the U.S. Department of Energy by Battelle Memorial Institute 


\section{DISCLAIMER}

This report was prepared as an account of work sponsored by an agency of the United States Government. Neither the United States Government nor any agency thereof, nor Battelle Memorial Institute, nor any of their employees, makes any warranty, expressed or implied, or assumes any legal liability or responsibility for the accuracy, completeness, or usefulness of any information, apparatus, product, or process disclosed, or represents that its use would not infringe privately owned rights. Reference herein to any specific commercial product, process, or service by trade name, trademark, manufacturer, or otherwise, does not necessarily constitute or imply its endorsement, recommendation, or favoring by the United States Government of any agency thereof, or Battelle Memorial Institute. The views and opinions of authors expressed herein do not necessarly state or reflect those of the United States Government or any agency thereof, or Battelle Memorial Institute.

\section{PACIFIC NORTHWEST LABORATORY operated by \\ BATTELLE MEMORIAL INSTITUTE for the \\ UNITED STATES DEPARTMENT OF ENERGY under Contract DE-AC06-76RLO 1830}

\begin{tabular}{|c|c|}
\hline \multicolumn{2}{|c|}{$\begin{array}{l}\text { Printed in the United States of America } \\
\text { Available from } \\
\text { National Technical Information Service } \\
\text { United States Department of Commerce } \\
5285 \text { Port Royal Road } \\
\text { Springfield, Virginia } 22161\end{array}$} \\
\hline \multicolumn{2}{|c|}{$\begin{array}{l}\text { NTIS Price Codes } \\
\text { Microfiche A01 }\end{array}$} \\
\hline \multicolumn{2}{|c|}{ Printed Copy } \\
\hline Pages & $\begin{array}{l}\text { Price } \\
\text { Codes }\end{array}$ \\
\hline $001-025$ & $\mathrm{~A} 02$ \\
\hline $026-050$ & $\mathrm{~A} 03$ \\
\hline 051-075 & A04 \\
\hline $076-100$ & A05 \\
\hline $101-125$ & $A 06$ \\
\hline $126-150$ & A07 \\
\hline $151-175$ & $\mathrm{~A} 08$ \\
\hline $176-200$ & A09 \\
\hline $201-225$ & A010 \\
\hline $226-250$ & A011 \\
\hline $251-275$ & A012 \\
\hline $276-300$ & A013 \\
\hline
\end{tabular}


ENERGY EFFICIENCY OF PACIFIC NORTHWEST AGRICULTURE IRRIGATION PUMPING SYSTEMS

G. L. Wilfert

B. J. Harrer

March 1987

Prepared for the Bonneville Power Administration under a Related Services Agreement with the U.S. Department of Energy Contract DE-AC06-76RLO 1830

Pacific Northwest Laboratory

Richland, Washington 99352 


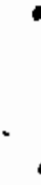

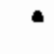

. 


\section{SUMMARY}

This document addresses the energy use and efficiency characteristics of pumping plants used to irrigate agricultural cropland in the Pacific Northwest. The principal focus of this document is on field information obtained from tests of irrigation pumping plants.

Electrical energy used to irrigate cropland consumes over 4 milition megawatt-hours of electricity annually in the Pacific Northwest. The mean pumping plant efficiency (a) for 1,134 tested irrigation pumping plants from throughout the Northwest was $57.3 \%$. This is below the $60 \%$ regional efficiency considered to be achievable. Further analysis of the pumping plant efficiency data indicated that there are distinct differences in pumping plant efficiencies between the subregions of Washington, Oregon, Idaho, and western Montana. Western Montana had the lowest pumping plant efficiency with a mean of $48.6 \%$, while Washington had the highest efficiency with a mean of $59.9 \%$.

Analysis of pumping data efficiencies was then separated into its component parts of motors and pumps. Field data suggest that, as a whole, the electric motors used to drive Pacific Northwest irrigation pumps have maintained the efficiency they had when purchased, regardless of motor horsepower. As expected, smaller horsepower motors have lower efficiencies than larger motors, with 25-hp motors having mean efficiencies of $88 \%$, while 100-hp motors have efficiencies of $91 \%$. Replacement of the standard electric motors currently used in the Pacific Northwest with high-efficiency motors presently available on the market would increase region-wide pumping plant efficiency and could save as much as 16.5 average MW of electricity by the year 2003. The costs of obtaining these savings would generally be less than 25 mills per kWh saved over a 20-year measure life.

Commercially available pumps for agricultural irrigation generally have efficiencies that range from 75 to $85 \%$. The small amount of field data

(a) Pumping plant efficiency represents the water horsepower energy output from a pumping plant divided by the energy input to the pumping plant. It is calculated as the energy efficiency of the electric motor multiplied by the efficiency of the irrigation pump. 
directly addressing pump efficiency indicates that many of the pumps used in irrigating agricultural crops are operating at efficiencies well below those generally available for new pumps, and below levels thought to be achievable under field operating conditions. For example, data on 516 pumps in Oregon indicated that $48 \%$ of the pumps operated at efficiencies below $65 \%$, $32 \%$ below $60 \%$, and $12 \%$ below 50\%. Another consideration in pump efficiency is the type of pump used. Field data for 404 centrifugal pumps showed the pumps to have a mean pump efficiency of $65.9 \%$ while field data for 71 turbine pumps had a mean pump efficiency of $61.8 \%$. This difference is statistically significant at a $0.001 \%$ level of confidence, indicating that lower pump efficiencies are generally associated with turbine pumps.

Pumping plant efficiency and total operating head data for 1,134 pumping plants located throughout the region were examined to determine if there was a relationship between the two variables. The pumping plant head from 0 to 1,000 feet was divided into 9 categories, and the mean efficiency was calculated for all pumping plants operating within each category. A comparison of the mean efficiencies for the first 5 categories shows a general increase in mean efficiency as operating head increases from 26 to 225 feet. An examination of these differences revealed that they are statistically significant at a 0.001 level of confidence. The mean efficiencies for the four categories of head, covering a range of 225 to 1,000 feet, indicated no significant relationship between increasing total operating head and pumping plant efficiency.

Field data relating pumping plant efficiency and pumping plant horsepower were also examined to see if a relationship existed. Six categories of pumping plant size were examined. Based on data from 1,134 pumping plants from throughout the region, there appears to be a general improvement in pumping plant efficiency with increases in plant size up to $150 \mathrm{hp}$. Differences between the calculated means for each category of plant size were found to be statistically significant up to a limit of $100 \mathrm{hp}$.

The results for total operating head and pump horsepower are consistent in that they reveal that irrigation pump efficiency generally increases as pumping power requirements are increased up to a certain leve1. Above this level, 
which was found to be 225 feet of operating head or 100 horsepower, little relationship between pumping plant efficiency and plant power requirements was found to exist. The consistency of results for total operating head and pump horsepower was to be expected, because the total operating head and pump horsepower levels of irrigation systems are generally well correlated.

Based on a review of available data and conversations with knowledgable experts, the primary reasons for low pumping plant efficiencies were found to be badly worn pumps and improper pump size. Pump wear is accelerated by sand pumped from either wells or open ditches, while pump cavitation results from pumping air. Air pumping can occur when air or air bubbles are taken directly into the pump, or when gas bubbles form at points of low pressure. Improper pump size arises where pumps are oversized to begin with, or parameters such as system flow and pressure change overall system operating conditions.

Few significant new technologies were found for improving irrigation pumping plant efficiencies. The keys to improving efficiencies were found to be better design of pumping plants to match system needs, and better pump maintenance. The strategy of the BPA and utilities for using information-based methods, such as pump testing programs, to improve pumping plant efficiencies, appears appropriate. However, it is believed that many of the methods of improving irrigation pump efficiencies have lifetimes that are too short to constitute viable long-term conservation resources. Although consideration should be given to using high-efficiency motors as a conservation resource, incorporation of other types of efficiency improvements as long-term programmatic conservation resources is not recommended.

Efforts need to be concentrated on delivering pumping plant information to irrigators in such a manner that they can understand and make use of the information. Results developed in this study show that current pump testing programs have generally been ineffective in increasing irrigator knowledge concerning the level of the efficiency of their pumping plants.

In the information programs, particular emphasis should be placed on assisting irrigators with low-efficiency pumps, such as those located in western Montana, those with turbine pumps, and those with pumps of less than $100 \mathrm{hp}$. Such an emphasis will enhance the cost-effectiveness of the program by 
targeting pump efficiency improvement efforts to those situations where the greatest improvements are possible. However, the overall energy savings of improving the efficiencies of small pumps are lixely to also be small because of the low percentage of total regional irrigation sector energy use that such pumps comprise. 


\section{CONTENTS}

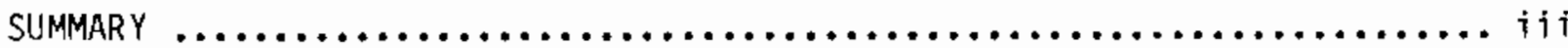

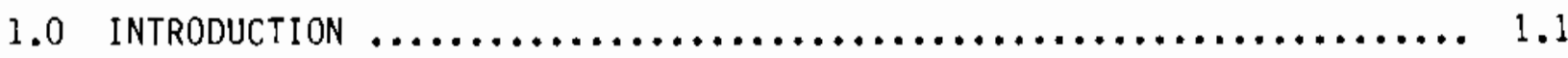

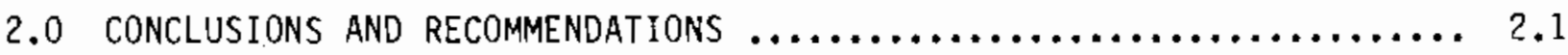

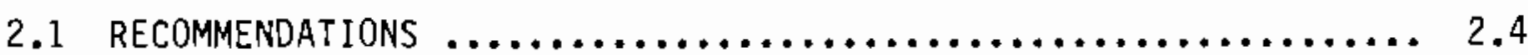

3.0 PUMPING IRRIGATION WATER $\ldots \ldots \ldots \ldots \ldots \ldots \ldots \ldots \ldots \ldots \ldots \ldots \ldots \ldots \ldots, 3.1$

3.1 GENERAL DESCRIPTION OF PACIFIC NORTHWEST AGRICULTURE $\ldots \ldots \ldots \ldots .3 .1$

3.1 .1 Irrigated Acreage $\ldots \ldots \ldots \ldots \ldots \ldots \ldots \ldots \ldots \ldots \ldots \ldots \ldots \ldots \ldots \ldots, 3.2$

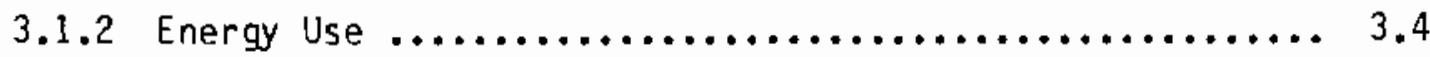

3.2 REgIONAL/SUBREgIONAL PUMPING PLANT EFFICIENCIES $\ldots \ldots \ldots \ldots \ldots . .5$

3.2.1 Pumping Plant Test Data ......................... 3.5

3.2.2 Regional Irrigation Pump Plant Efficiency $\ldots \ldots \ldots \ldots \ldots .6$

3.2 .3 Subregional Variations $\ldots \ldots \ldots \ldots \ldots \ldots \ldots \ldots \ldots \ldots \ldots \ldots \ldots \ldots \ldots \ldots, 3.8$

4.0 CHARACTERISTICS OF IRRIGATION MOTORS, PUMPS,

AND PUMPING PLANTS $\ldots \ldots \ldots \ldots \ldots \ldots \ldots \ldots \ldots \ldots \ldots \ldots \ldots \ldots \ldots \ldots \ldots \ldots \ldots \ldots \ldots \ldots, 1$

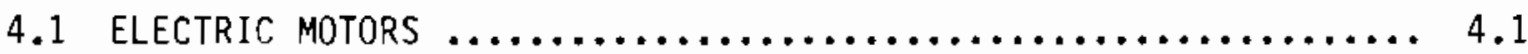

4.1.1 General Information on Motor Efficiency ............. 4.1

4.1.2 Field Information on Motor Efficiency .............. 4.5

4.2 IRRIGATION PUMPS $\ldots \ldots \ldots \ldots \ldots \ldots \ldots \ldots \ldots \ldots \ldots \ldots \ldots \ldots \ldots, 4.8$

4.3 PUMPING PLANTS $\ldots \ldots \ldots \ldots \ldots \ldots \ldots \ldots \ldots \ldots \ldots \ldots \ldots \ldots \ldots, 4.12$

4.3.1 Total Operating Head Versus Plant Efficiency .......... 4.13

4.3.2 Horsepower Versus Pumping Plant Efficiency ........... 4.14

5.0 LOW PUMping Plant efficiencies $\ldots \ldots \ldots \ldots \ldots \ldots \ldots \ldots \ldots \ldots \ldots \ldots, 5.1$

5.1 BPA IRRIGATION SYSTEM AUDIT INFORMATION $\ldots \ldots \ldots \ldots \ldots \ldots \ldots \ldots \ldots \ldots \ldots \ldots \ldots$

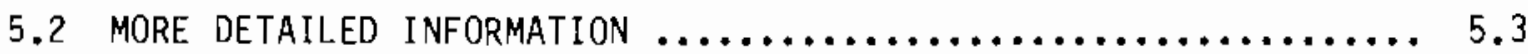

5.3 IRRIgATOR PERCEPTIONS OF PUMPING PLANT EFFICIENCIES $\ldots \ldots \ldots \ldots .5 .10$ 
6.0 REPLACEMENT EqUIPMENT $\ldots \ldots \ldots \ldots \ldots \ldots \ldots \ldots \ldots \ldots \ldots \ldots \ldots \ldots \ldots \ldots \ldots \ldots \ldots$

6.1 ENERGY EFFICIENT MOTORS $\ldots \ldots \ldots \ldots \ldots \ldots \ldots \ldots \ldots \ldots \ldots \ldots \ldots \ldots \ldots \ldots$

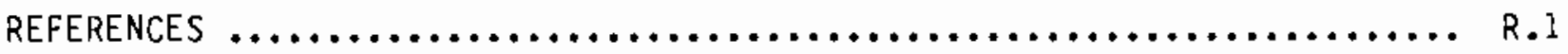

APPENDIX A--LOW/HIGH PUMPING PLANT EFFICIENCIES $\ldots \ldots \ldots \ldots \ldots \ldots \ldots \ldots \ldots \ldots$ 


\section{FIGURES}

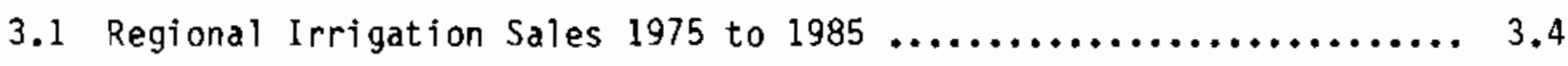

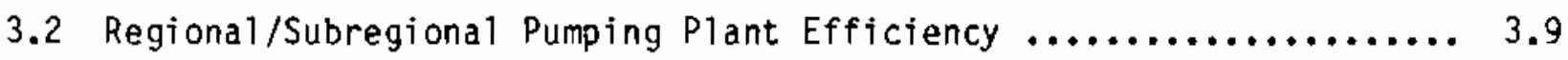

4.1 Motor Efficiency Distribution $\ldots \ldots \ldots \ldots \ldots \ldots \ldots \ldots \ldots \ldots \ldots . \ldots . \ldots . . . \ldots$

4.2 Motor Efficiency Versus Horsepower ...................... 4.7 


\section{$\underline{\text { TABLES }}$}

3.1 Estimated Irrigated Acres by Region/Subregion and Water Source 1980

3.2 Distribution of Pacific Northwest Irrigation Pumping Plant Efficiencies

3.3 Pumping Plant Efficiency $\ldots \ldots \ldots \ldots \ldots \ldots \ldots \ldots \ldots \ldots \ldots \ldots \ldots \ldots \ldots \ldots$

3.4 Calculated Students t Values and Significance Levels for Differences in Mean Pump Efficiencies Between Geographic Areas

4.1 Ful1-Load Efficiencies of NEMA Design B Standard Three Phase

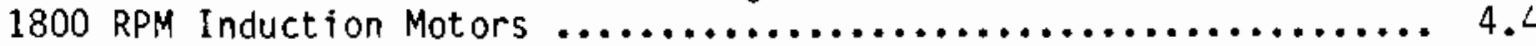

4.2 Profile of Irrigation Motor Efficiency $\ldots \ldots \ldots \ldots \ldots \ldots \ldots \ldots$

4.3 Motor Horsepower Versus Field Efficiency $\ldots \ldots \ldots \ldots \ldots \ldots \ldots \ldots \ldots$

4.4 NEMA and Field Electric Motor Data $\ldots \ldots \ldots \ldots \ldots \ldots \ldots \ldots \ldots \ldots$

4.5 Energy Efficiency Profile for 516 Oregon Irrigation Pumps Horsepower Versus Pump ............................... 4.10

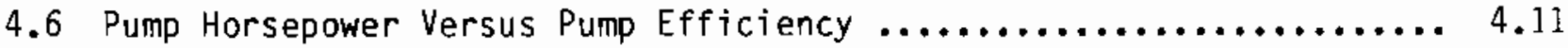

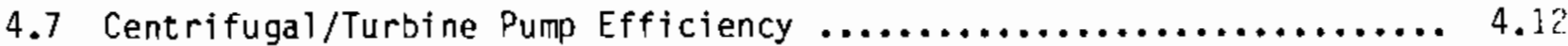

4.8 Profile of the Total 0perating Head for 516 Pumps $\ldots \ldots \ldots \ldots \ldots \ldots .16$

4.9 Total Operating Head Versus Pumping Plant Efficiency ........... 4.15

4.10 Pumping Plant Horsepower Versus Pumping Plant Efficiency ......... 4..1t

5.1 Causes of Low Irrigation Pumping Plant Efficiencies Ranked

from Most Frequent ly Mentioned to Least Frequent ly Mentioned ...... 5.2

5.2 Statistically Weighted Mean Pumping Plant Efficiencies by Usage Strata Computed from Telephone Survey Results ............ 5.11

5.3 Statistically Weighted Frequency Distribution for Year of Most Recent Pump Test ................................ 5.13

5.4 Statistically Weighted Frequency Distribution of Irrigation Pumping Plant Tests by Performing Organization 
5.5 Segmentation of Information on Statistically Weighted Current Average Pumping Plant Efficiency by Those Having a Pump Test Versus Those Not Having a Pump Test ......................... 5.14

6.1 High Efficiency Motors $\ldots \ldots \ldots \ldots \ldots \ldots \ldots \ldots \ldots \ldots \ldots \ldots \ldots \ldots \ldots . \ldots \ldots$

6.2 Potential Electrical Energy Savings from Replacing 4,865 Pumping Plant Electric Motors with High-Efficiency Motors ........ 6.3 


\section{GLOSSARY}

Irrigation Pump - Equipment used to lift and pressurize water for irrigation that does not include the electric motor or other prime mover.

Irrigation Motor - Equipment used to power the irrigation pump. Almost all irrigation motors in the Pacific Northwest are powered by electricity.

Irrigation Pumping - Combination of irrigation pump and irrigation motor Plant equipment used to lift and pressurize water for irrigation.

Efficiency - Measure of the ratio of power output to power input. 


\subsection{INTRODUCTION}

Irrigation-aided agriculture is an important economic sector providing jobs and income throughout the Northwest. Agricultural production and food processing together provide an estimated 250,000 jobs or about $7 \%$ of the employment of the region. A very large portion of the agricultural products produced in the region are grown on irrigated cropland. The pumping of irrigation water to these crops creates a large requirement for electric power and constitutes an important electrical load on the electric generation facilities of the region during the growing season.

Since the passage of the Pacific Northwest Electric Power Planning and Conservation Act in December of 1980, the region has been involved in an extensive planning program to forecast electric generation needs and to define the role of conservation. The purpose of this planning process is to ensure that there is a sufficient and reliable electrical energy supply to support the various sectors of the Northwest economy at the lowest practical cost.

Conservation is considered an energy supply resource within the planning process because for each megawatt of electricity conserved, one less megawatt needs to be generated. Conservation of electrical energy is an important resource in meeting future electrical energy needs.

Previous assessments of the electrical conservation resource in irrigated agriculture focused on two aspects of irrigation: 1) more efficient water application systems, and 2) water application scheduling improvements for both new and existing acreage. The electrical conservation potential in these two areas is estimated to reduce the irrigation electrical load in 2005 by $14 \%$ (NPPC 1986a). These two aspects of irrigation conservation do not include potential energy savings associated with improving the efficiencies of irrigation pumping plants.

The purpose of this study is to determine whether a technically viable conservation resource exists through improving the energy efficiency of irrigation pumping plants in the Pacific Northwest region. In association with this ohjective, information was developed on the current efficiencies and other characteristics of irrigation pumping plants in the region. Analyses were then 
performed on the causes of low and high pumping plant efficiencies in order to assess what actions and technologies may be available for improving pumping plant efficiencies.

This report is organized into six chapters. Chapter 2.0 presents the major findings and conclusions of the study. Chapter 3.0 addresses irrigation pumping plant efficiency from a regional and subregional perspective. Chapter 4.0 focuses on the efficiency of specific components of the pumping plant; the relationships between pumping plant efficiency, total operating head, and horsepower. In Chapter 5.0 specific power plants are selected and potential reasons for low or high pumping plant efficiencies, as measured in field pumping plant tests, are characterized. Chapter 5.0 also presents information on irrigators' perceptions of their pumping plant efficiencies. Chapter 6.0 summarizes the results of a case study of methods for improving pumping plant efficiency. 


\subsection{CONCLUSIONS AND RECOMMENDATIONS}

An examination of data from irrigation pumping plant performance tests conducted on 1,134 pumping plants in the Northwest region showed pumping plant efficiencies ranging from 9 to $83 \%$. The mean efficiency for these plants was 57.3\%. This level of efficiency is not unreasonable over a large region. It is, for example, similar to the $56.9 \%$ efficiency measured for 1,679 pumping plants in California during the early 1970s. Given an average efficiency of $57.3 \%$, there appears to be roon for improving the region's pumping plant efficiency. An overall regional improvement of existing irrigation pumping plant efficiencies to an average of $60 \%$ is considered achievable, and is estimated in this study to represent a current potential savings of almost 100,000 MWh of electricity annualiy (equivalent to about 11 average megawatts).

Examination of pumping plant data showed that there is considerable variation in pumping plant efficiency, with about one quarter of the pumping plants tested having efficiencies at or below 50\% and over half having efficiencies below the $60 \%$ level, which is generally considered achievable. The average pumping plant efficiency also showed variation from subregion to subregion. Western Montana as a subregion of the Northwest was estimated to have a mean pumping plant efficiency of $48.6 \%$. This Tevel of efficiency is significantly below that identified for the Idaho $(54.4 \%)$, Oregon $(58.2 \%)$ and washington $(59.9 \%)$ subregions.

Individual plant performance data was examined to determine the efficiency characteristics of individual pumping plant components, including motors and pumps. At the component level, field data indicates that a strong positive relationship exists at the regional level between pumping plant motor size and motor efficiency. For example, the mean efficiency for field motors with horsepower over $100 \mathrm{hp}$ is estimated to be $91.8 \%$, a ful1 5 percentage points above motors with 0 to $25 \mathrm{hp}$. In addition, the data indicates that electric motors under field conditions tend to hold their efficiencies even after many years of field operation. Thus, for the majority of electric motors used in irrigated agriculture, poor motor maintenance does not appear to be a major contributor to reduced pumping plant efficiency. 
Field data on the pump component of irrigation pumping plants indicates that pump component efficiencies are not influenced by increases in pump size from 0 to $150 \mathrm{hp}$. The efficiencies of pumps in the field data ranged from a minimum recorded efficiency of $16 \%$ to a maximum recorded efficiency of $89 \%$. Approximately one-third (32.4\%) of the pumps in the data set evaluated had pump efficiencies of $60 \%$ or below. About $12 \%$ of the pumps were identified as havir! efficiencies below $50 \%$.

Additional data analysis was conducted to identify the impacts of the pumping plant characteristics of total operating head and pump size on tota1 pumping plant efficiencies. Statistical analysis of the total operating head data found that, for a range of operating head from 26 to 225 feet, pumping plant efficiency increases with increasing total operating head. Pumping plants with operating heads above 225 feet demonstrated no distinct improvement or decline in pumping plant efficiency as total operating head increased.

Based on the field data used in this assessment, there appears to be a general improvement in pumping plant efficiency as pumping plant horsepower increases up to $150 \mathrm{hp}$. Statistical analysis of this data could indicate that this general trend is significant up to $100 \mathrm{hp}$. Above $100 \mathrm{hp}$, there does not appear to be a significant positive or negative relationship between plant horsepower and plant efficiency.

These results are similar to those for total operating head in that pumping plant efficiency was found to increase as power requirements were increased up to a certain level. Beyond this level, no relationship between plant efficiencies and power requirements was found. The consistency between the results for total operating head and pump horsepower was to be expected because studies have shown that these two measures of pumping plant size are generally well correlated.

The major causes of low pumping plant efficiencies were examined through analysis of BPA program audit information and conversations with knowledgable experts. The results of this examination revealed that the primary causes of low pumping plant efficiencies are worn and improperly sized pumps. Sand pumping and cavitation caused by air pumping were found to be major causes of 
accelerated wear in pumps. Use of pumps with design head and flow rates larger than irrigation system operating needs were found to be the major example of improperly sized pumps.

No examples of commercially available new technology that would produce significant improvements in pumping plant efficiency were identified during this study. Instead, the keys to improving pumping plant efficiencies were found to be better design of pumping plants and better maintenance. The only hardware change that was identified as being an available and long-lasting method of improving pumping plant efficiency was the replacement of standard electric motors with high-efficiency electric motors. A preliminary analysis using the Irrigation Sector Energy Planning (ISEP) model revealed that approximately 11 average MW could be saved from such replacement on existing sprinkler irrigated acres and 5.5 average $M W$ could be saved on new sprinkler irrigated acres. These savings could generally be obtained at a cost of 25 mills per kWh saved or less over a 20-year measure life.

Analysis of the results of a survey of 1,244 Pacific Northwest irrigators revealed a low level of awareness of pumping plant efficiency levels. A majority of irrigators could not provide an estimate of their average plant efficiency when asked. From those providing estimates the mean efficiency was $76 \%$. This estimate is significant Ty higher than the mean of approximately $57 \%$ obtained in the field tests and indicates that irrigators feel their pumping plant efficiencies are significantly higher than they actually are.

In addition, irrigator awareness concerning pumping plant efficiency levels did not appear to be influenced by whether they had a pump test. The proportions of irrigators unable to provide an estimate of their pumping plant efficiency levels and the mean efficiency levels for those providing estimates were nearly identical for those irrigators who reported having pump tests as for those irrigators not having pump tests. The low levels of measured energy efficiency present in many Pacific Northwest irrigation pumping plants, and the low awareness of irrigators concerning current pumping plant efficiency levels, indicate that energy savings are available through improving pumping plant efficiencies. 


\subsection{RECOMMENDATIONS}

Based on the findings of this study that the primary methods of improving irrigation pumping plant efficiencies are through better design and better maintenance of these plants, it appears that information-based methods of improving plant efficiencies, such as pump testing programs, are appropriate for the BPA and utilities. However, it should be noted that current programs do not appear to have been effective in increasing awareness of current pumping plant efficiency levels. Consideration should be given to providing educational seminars for farmers to learn about pump inspection techniques and other methods of providing information to facilitate pump efficiency improvements.

There are several ways that the regionwide efficiency of $57.3 \%$ for pumping irrigation water may be improved. Measures could be implemented to increase the efficiency of each pumping plant a small amount. An example of this would he to take one component of a pumping plant, such as the electric motor, and improve its efficiency. A second method would be to encourage major energy efficiency improvements in pumping plants having very low efficiencies. To make major efficiency improvements in these plants may require several approaches including changes in plant maintenance and operation, changes in plant design, and replacement of standard efficiency motors with highefficiency motors. Plants with relatively low efficiencies such as those in western Montana, turbine pumps, and pumps less than $100 \mathrm{hp}$ in size, would be targeted in this method. Such targeting would be the most efficient approach because resources would be directed to facilitating pump efficiency improvements in those situations where the largest improvements are possible. However, the total energy savings from improving the efficiency of small pumps are likely to also be small because of the low-percentage of total irrigation sector energy use that these pumps comprise.

Because improving pumping plant efficiencies is related to so many variables involving improved design and maintenance practices, quantification of the potential energy savings from efficiency improvements is an uncertain and unreliable process. In addition, many of the methods of improving pump efficiencies may have lifetimes that are too short for them to be considered viable. 
long-term conservation resources. However, the results of a preliminary analys is of high-efficiency motors indicates consideration should be given to using high-efficiency motors as a conservation resource in the irrigation sector. With the exception of high-efficiency motors, further efforts to quantify the energy savings and cost effectiveness of irrigation pumping plant efficiency improvements do not appear to be warranted. 


\subsection{PUMPING IRRIGATION WATER}

The amount of electricity used to irrigate agricultural corps constitutes a significant electrical load in selected areas of the Pacific Northwest region during the spring, summer and fall. The following sections provide a general description of agriculture in the region, the present requirement for electrical energy by the irrigated agriculture sector, and area-wide pumping plant efficiency at both the regional and subregional level.

\subsection{GENERAL DESCRIPTION OF PACIFIC NORTHWEST AGRICULTURE}

The croplands of the Pacific Northwest are widely dispersed. The largest contiguous blocks of cropland are located in the Snake River Basin of southern Idaho and eastern Oregon, the Columbia Basin of eastern Washington and northcentral Oregon, and the Willamette Valley of western Oregon. Other noteworthy concentrations of productive cropland are located in the Yakima River drainage basin of south-central Washington, and the Deschutes, Klamath, and Rogue drainage basins in Oregon (Highsmith 1979). Sizeable blocks of cropland are also located in the valleys of the Clark Fork, Flathead, and Bitterroot Rivers in western Montana (PNRBC $1971 \mathrm{App.} \mathrm{IX).} \mathrm{In} \mathrm{addition,} \mathrm{the} \mathrm{valleys} \mathrm{of} \mathrm{many} \mathrm{of} \mathrm{the}$ smaller streams of the region contribute to the region's total cropland acreage (Highsmith 1979). Total cropland is estimated to encompass some 20 million acres of Idaho, Oregon, Washington, and Western Montana (PNRBC 1979).

The amount of precipitation, the timing of this moisture, and the moisture-holding capacity of the soil are important factors in the types of crops that can be grown in various areas of the Pacific Northwest. On average, the region receives approximately 27 inches of precipitation annually. However, large variations between geographic subregions and between seasons occur. In some areas, crops can not be grown commercially without irrigation.

The amount of precipitation and its distribution throughout the region is heavily influenced by regional landforms. The dominant feature is the Cascade Mountain Range which divides the region on the basis of precipitation. The area west of the Cascades has annual precipitation consistently above 15 inches; the area to the east receives less than 15 inches (except in 
mountain zones). East of the Cascade Range, in central Oregon and Washington, precipitation decreases rapidly to 10 inches or less in the valleys and on the plateaus. Further east in the Snake River Plain, precipitation ranges from 6 to 15 inches annually (PNRBC 1969 App. II).

In terms of agricultural crop requirements for water, the use of annual average precipitation as an indicator of water availability can be highly mis. leading because of variable seasonal precipitation patterns. The fact that very little precipitation occurs in the region during July, August, and September 's often overlooked. Summers with 70 to 80 consecutive days of no measurable pre.cipitation are normal. About $60 \%$ of the annual precipitation normally occurs during the months of December through April. Consequently, even areas west of the Cascade Mountains may suffer from summer drought, though annual precipitation in this subregion averages 24 inches or more (PNRBC 1979).

Therefore, irrigation water is applied to agricultural crops extensiveiy throughout the region. Irrigation water is absolutely essential if crops are to be grown on a large portion of the available cropland located in the Columbia and Snake basins. Other croplands in the arid and semi-arid lands east of the Cascade Mountains require water to supplement precipitation if this land is farmed by methods other than dryland farming. Supplemental water provided through irrigation systems is also used west of the Cascade Mountains to insure that crop yields do not suffer during the dry season.

\subsubsection{Irrigated Acreage}

It is estimated that in 1980 over 7.7 million acres of the 20 million acres of cropland in the region were irrigated. Of the 7.7 million acres of irrigated cropland, approximately $95 \%$ are located within the arid and semiarid subregions east of the Cascade Mountains. (a)

To overcome the seasonal and geographic variation in regional precipitation, extensive efforts have been made to store a portion of the precipitation from the 0ecember through April period. The retained water is then distributerf

(a) Unpublished data supplied by Dave Ricks, Northwest Economic Associates, Vancouver, Washington. 
through surface water delivery systems so that it is available to farm irrigation systems during the irrigation season. Groundwater aquifers are also important in the supply and distribution of water for irrigation. These aquifers supply water directly to irrigation wells and springs. In addition, groundwater aquifers store and release water to the surface waterways of the region. In a number of drainage basins of the arid and semiarid subregions, a significant portion of the surface water available for irrigation is provided through groundwater discharges.

Surface water resources are the predominant source of irrigation water in the region. Approximately $75 \%$ of all regional irrigation water is drawn from surface water sources, although the proportion of total irrigation comprised by surface water and groundwater irrigation differs from subregion to subregion. Table 3.1 shows that groundwater plays a slightly larger role in irrigation west of the Cascade Mountains than east of the mountains, and that western Montana and Oregon lead in the percentage of acres irrigated from surface water, while Idaho and Washington lead in the percentage of acres irrigated using groundwater.

TABLE 3.1. Estimated Irrigated Acres by Region/Subregion and Water Source in 1980

\begin{tabular}{|c|c|c|c|c|}
\hline & Area & $\begin{array}{c}\text { Acres } \\
\text { Irrigated } \\
(1000) \\
\end{array}$ & $\begin{array}{l}\text { Groundwater } \\
(\%)\end{array}$ & $\begin{array}{c}\text { Surface } \\
\text { Water } \\
(\%) \\
\end{array}$ \\
\hline Pacific & Northwest Region & 7708.5 & 24.8 & 75.2 \\
\hline East of & Cascades & 7266.5 & 24.2 & 75.8 \\
\hline West of & Cascades & 442.0 & 34.3 & 65.7 \\
\hline Idaho & & 3529.1 & 36.0 & 64.0 \\
\hline Oregon & & 1716.4 & 13.8 & 86.2 \\
\hline Washingt & ton & 1813.0 & 21.1 & 78.9 \\
\hline Western & Montana & 650.0 & 3.5 & 96.5 \\
\hline
\end{tabular}

Source: Unpublished data supplied by Dave Ricks, Northwest Economic Associates, Vancouver, Washington. 


\subsubsection{Energy Use}

Sales of electricity to the agricultural sector for pumping irrigation water have fluctuated significantly within the region, from approximately 425 average megawatts to slightly over 600 average megawatts during the 1975 to 1984 period as shown in Figure 3.1 (BPA 1985a). Electricity sales for pumping irrigation water for 1984 are estimated to be approximately 4.0 million megawatt-hours or about 450 average megawatts. The dramatic fluctuation in electrical energy consumption by irrigation pumping is related to shifts in cropping practices, changes in weather, and adoption of water and energy conservation measures (BPA 1985a). Even with the current reduced level of irrigation requirement for electricity, the demand for 4.0 million megawatt-hours of electricity for irrigation constitutes an important electrical load during the summer season.

In a previous related study, the total potential energy savings for conservation measures applied to irrigated agriculture were estimated to be 132 average megawatts in 1985 and 155 megawatts by the year 2000 (Harrer, et al. 1985). This estimate excludes irrigation systems and estimated acreage

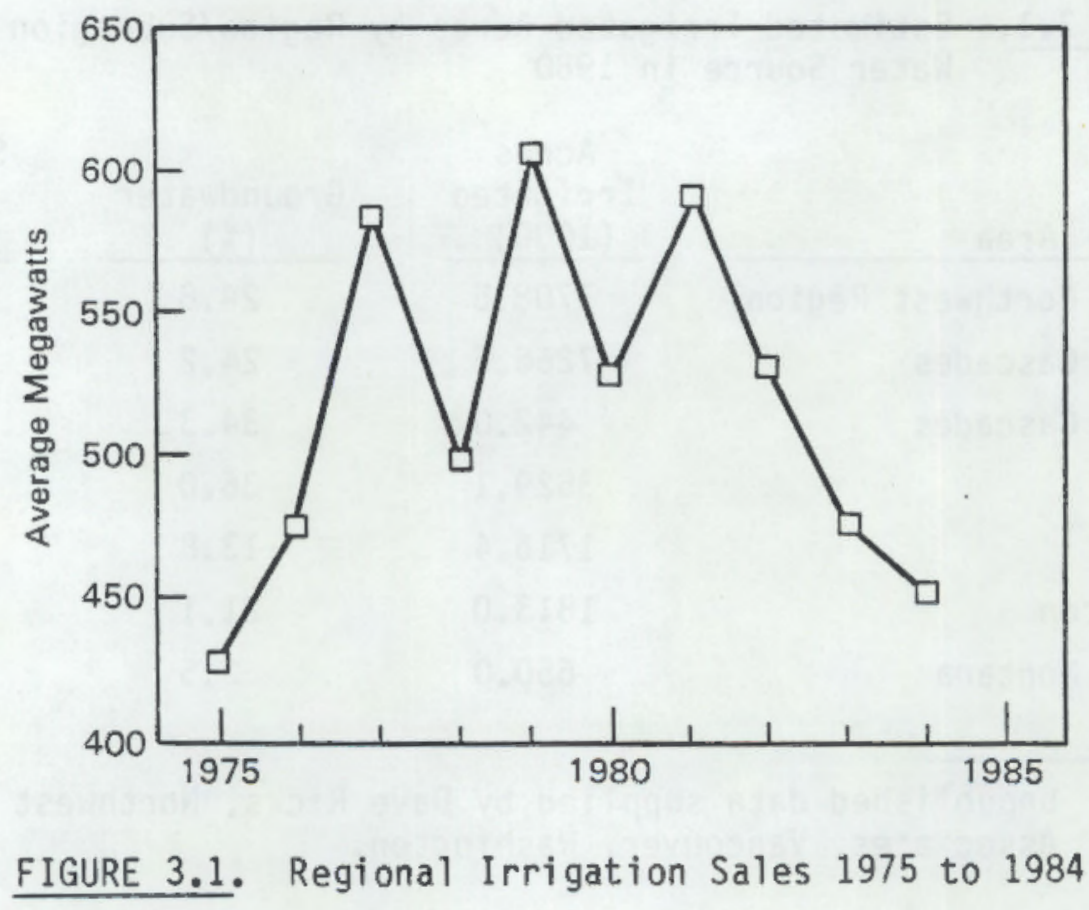


on which conservation has already been achieved through implementation of available conservation measures, and incorporates the interactive effects between implemented conservation measures.

The conservation measures considered available for immediate use in the irrigation sector of the Northwest are; reduced-pressure irrigation, improved design of pipe fittings and mainlines, improved irrigation scheduling, and pump efficiency improvements. Energy savings were estimated in the previous study for the first three conservation measures, but no savings were included for pump efficiency improvements because of a lack of available field data required to develop such estimates and uncertainty about whether pump efficiency improvements constitute a viable conservation resource. Thus, the remainder of this assessment focuses on selected aspects of the efficiencies of pumping plants used in irrigating agricultural crops.

\subsection{REGIONAL/SUBREGIONAL PUMPING PLANT EFFICIENCIES}

The efficiency of pumping plants used in irrigating crops can vary considerably from plant to plant; however, a pumping plant efficiency of $65 \%$ is generally considered to be achievable (Hanson 1983). The actual efficiency of a pumping plant is definable only through field testing. Over the last 8 to 10 years, numerous tests of pumping plant efficiencies have been conducted on irrigation pumping plants in the region. The efficiency data presented in this section is drawn from the results of approximately 1,100 of these tests.

\subsubsection{Pumping Plant Test Data}

Rising energy costs and forecasts of energy shortages since the early 1970 s have combined to increase the interest of farm operators, electric utility firms, and regional energy planning entities in identifying the energy efficiency of irrigation pumping plants and determining what cost-effective repair, maintenance, and operation considerations should be implemented. Numerous pumping plant efficiency tests have been conducted by farm operators and private consultants, on their own and under incentive programs promoted through electric utilities. Although the results of all of these tests have 
never been compiled, it is generally understood by those conducting the tests that the efficiency of pumping plants vary over a wide range from $30 \%$ or less to over $75 \%$.

The wide range of pumping plant efficiencies obscures the average pumping plant efficiency for the region. Average estimates of 59 and $60 \%$ for surface and groundwater pumps have been used in previous studies (Harrer, et al. 1985). To define more clearly the average pumping plant efficiency for the region and to address the question of subregional differences, two separate data bases of irrigation pumping plant test information were combined. The information used in this assessment includes pumping plant test data from BPA's irrigation system audit program conducted throughout the Pacific Northwest region from 1982 to 1984 and the Oregon Water Resources Research Institute's (OWRI) pump test data for Oregon in 1979 and 1980.

\subsubsection{Regional Irrigation Pump Plant Efficiency}

Review of the test data from the irrigation pump plant tests indicates that a very wide range of pumping plant efficiencies exists. Pumping plant efficiencies as low as $9 \%$ and over $86 \%$ were measured. For pumping plant efficiencies to be above $86 \%$ suggests that the motor is at least $95 \%$ efficient and the pump is at least $90 \%$ efficient. Normally, pumping plant efficiencies above $86 \%$ are not expected in field operations. Thus, the 17 pump plants that were recorded as having overa 1.1 plant efficiencies above $86 \%$ were not included in the data used in this assessment. Omission of these 17 pumping plants resulted in a data base of 618 pumping plant efficiency estimates for the BPA data and 516 estimates for the OWRI data, for a combined total of 1,134 pumping plants in the data base.

Analysis of the efficiency data for the 1,134 pumping plants shows that the mean efficiency for these plants is $57.3 \%$. This value is slightly below the regional values for surface and groundwater pumping plants used by Harrer (1985). On the other hand, the $57.3 \%$ efficiency value for the Pacific Northwest is very close to the average pumping plant efficiency found in 1,679 pump performance tests in California (University of California 1978). If the pumping plant data used in this analysis is representative of regional irrigation 
pumping plants, then the standard error of 0.375 suggests that the true mean efficiency for pumping plants in the region lies between 56.6 and $58.1 \%$ efficiency, at a confidence level of $95.5 \%$.

Table 3.2 provides a profile of regional pumping plant efficiency. To generate the efficiency profile, pumping plants with efficiencies between 25 and $80 \%$ are separated into 11 categories each covering 5 percentage points. The number of pumping plants having efficiency in each category is accumulated to provide the profile shown in Table 3.2. The distribution of the 1,134 pumping plants across these categories appears to be slightly skewed to the right with $16.9 \%$ of the 1,134 plants falling into the 56 to $60 \%$ efficiency category and $16.4 \%$ of the pumping plants falling into the 61 to $65 \%$ efficiency category. Some $10.2 \%$ of the pumping plants tested had efficiencies below $41 \%$, while $12.5 \%$ had efficiencies above $70 \%$. About one quarter of the tested pumping plants had efficiencies at or below $50 \%$, suggesting that there may be

TABLE 3.2. Distribution of Pacific Northwest Irrigation Pumping Plant Efficiencies

\begin{tabular}{|c|c|c|c|}
\hline $\begin{array}{l}\text { Pumping Plant } \\
\text { Efficiency }\end{array}$ & $\begin{array}{l}\text { No. of } \\
\text { Syst ems }\end{array}$ & $\begin{array}{l}\text { Percent } \\
\text { of Tests } \\
(\%)\end{array}$ & $\begin{array}{c}\text { Cumulat ive } \\
\text { Percent } \\
(\%)\end{array}$ \\
\hline$\leqslant 25 \%$ & 23 & 2.0 & 2.0 \\
\hline 26 to $30 \%$ & 15 & 1.3 & 3.4 \\
\hline 31 to $35 \%$ & 30 & 2.6 & 6.0 \\
\hline 36 to $40 \%$ & 48 & 4.2 & 10.2 \\
\hline 41 to $45 \%$ & 72 & 6.3 & 16.6 \\
\hline 46 to $50 \%$ & 106 & 9.3 & 25.9 \\
\hline 51 to $55 \%$ & 150 & 13.2 & 39.2 \\
\hline 56 to $60 \%$ & 192 & 16.9 & 56.1 \\
\hline 61 to $65 \%$ & 186 & 16.4 & 72.4 \\
\hline 66 to $70 \%$ & 171 & 15.1 & 87.6 \\
\hline 71 to $75 \%$ & 84 & 7.4 & 95.0 \\
\hline 76 to $80 \%$ & 51 & 4.5 & 99.5 \\
\hline \multirow[t]{2}{*}{$>80 \%$} & 6 & 0.5 & 100.0 \\
\hline & 1134 & & \\
\hline
\end{tabular}


economic and energy savings benefits to making pumping plant repair/ modification/replacement decisions to improve pumping plant efficiency.

\subsubsection{Subregional Variations}

As discussed earlier the region is large and geographically diverse. Even so, given that pumping technology and the condition of the equipment should be essentially equal in all subregions, it would be expected that pumping plant efficiencies should not differ significantly among subregions.

However, based on data from the BPA irrigation system audit program, there appears to be significant differences in pumping plant efficiencies between subregions. Ordering four subregions by pumping plant efficiency from low to high, western Montana with a mean efficiency of $48.6 \%$ (based on data for 122 pumping plants, i.e. $n=122$ ) is followed by Idaho, which has a mean of $54.4 \%$ $(n=28)$, Oregon has a mean of $58.2 \% \quad(n=60)$, and Washington has a mean of $59.9 \%$ $(n=408)$. The small number of pumping plant data for the Idaho subregion leads to a fairly wide interval ( $\mp 4.72$ percentage points at the $95.5 \%$ confidence leve1) around a mean pumping plant efficiency of $54.4 \%$. For the other subregions, the standard errors are much smaller. Only a small difference (0.9 percentage points) was found between the mean efficiency of the OregonOWRI data and the Oregon-BPA data. The means and intervals in pumping plant efficiencies estimated for the four geographic subregions are illustrated graphicaliy in Figure 3.2 .

It appears from the information presented in Table 3.3 and Figure 3.2 that differences exist between geographic subregions in terms of pumping plant efficiency. To determine the statistical significance of these differences, $t$ values were computed for the differences in mean pumping plant efficiencies between subregions. The results of this analysis are shown in Table 3.4. Note from Table 3.4 that the differences in mean efficiencies were determined to be statistically significant for at least a $5 \%$ level of confidence for all comparisons except Idaho-BPA data efficiencies versus Oregon-BPA data efficiencies. The small sample size for Idaho-BPA and Oregon-BPA no doubt contributed to the lack of statistical significance for this comparison. In addition, the 


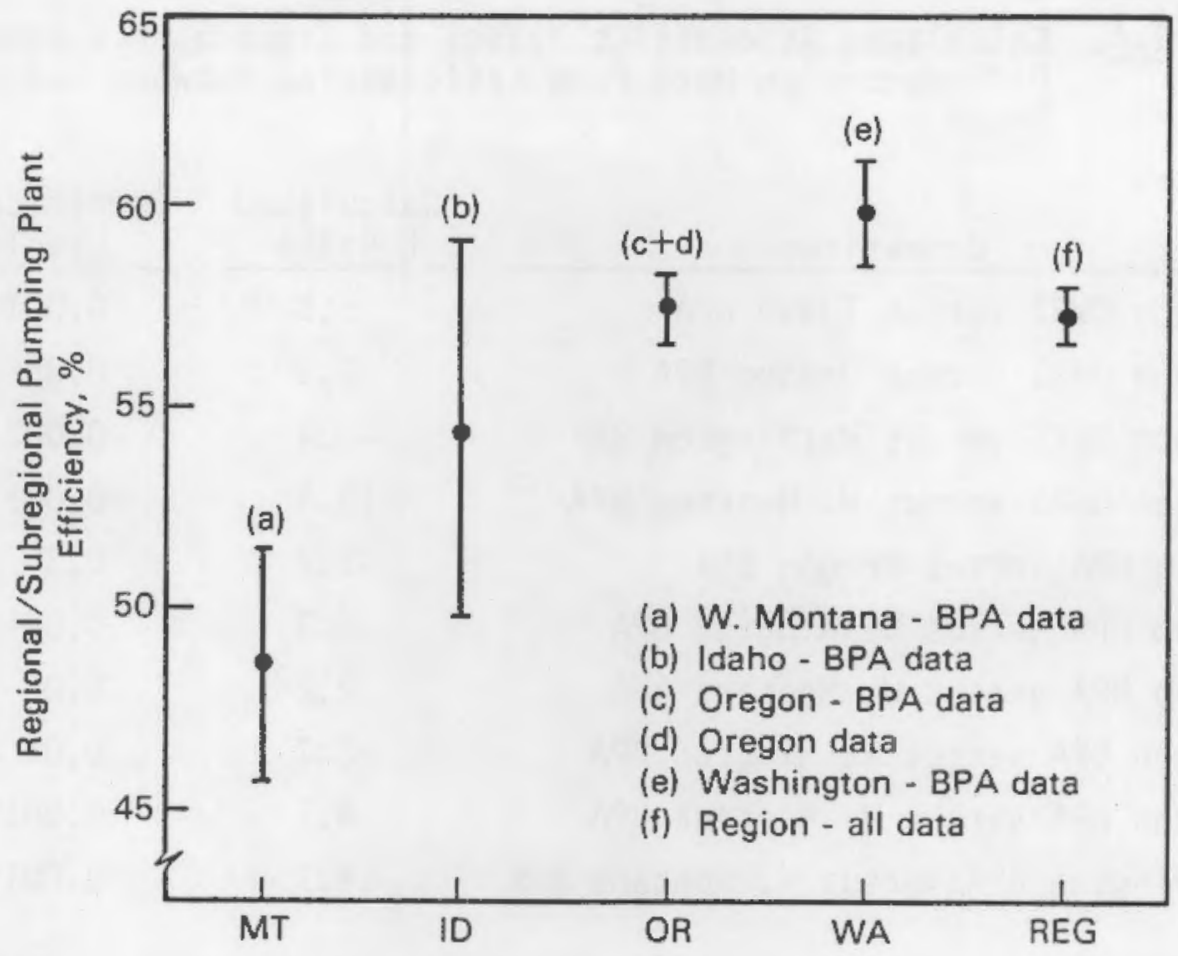

FIGURE 3.2. Regional/Subregional Pumping Plant Efficiency

TABLE 3.3. Pumping Plant Efficiency

\begin{tabular}{|c|c|c|c|c|c|c|c|}
\hline Area & $\begin{array}{l}\text { No. of } \\
\text { Units }\end{array}$ & $\begin{array}{l}\text { Mean } \\
(\%) \\
\end{array}$ & $\begin{array}{c}\text { Interval (a) } \\
(\%) \\
\end{array}$ & $\begin{array}{l}\text { Std } \\
\text { Dev. }\end{array}$ & $\begin{array}{c}\text { Std } \\
\text { Error }\end{array}$ & $\begin{array}{l}\text { Min } \\
\text { (\%) }\end{array}$ & $\begin{array}{l}\operatorname{Max} \\
(\%) \\
\end{array}$ \\
\hline Region-all data & 1134 & 57.3 & 56.6 to 58.1 & 12.7 & 0.75 & 9.0 & 83.0 \\
\hline OWRI Data (b) & 516 & 57.3 & 56.4 to 58.3 & 10.8 & 0.95 & 14.0 & 79.0 \\
\hline Region-BPA Data $(c)$ & 618 & 57.3 & 56.2 to 58.4 & 14.0 & 1.13 & 9.0 & 83.0 \\
\hline Idaho-BPA Data $(c)$ & 28 & 54.4 & 49.7 to 59.1 & 12.5 & 4.72 & 15.0 & 72.0 \\
\hline Oregon-BPA Data $(c)$ & 60 & 58.2 & 55.3 to 61.1 & 11.3 & 2.92 & 32.0 & 77.0 \\
\hline Washington-BPA Data $(c)$ & 408 & 59.9 & 58.6 to 61.2 & 13.0 & 1.29 & 9.0 & 83.0 \\
\hline W. Montana-BPA Data (c) & 122 & 48.6 & 45.8 to 51.4 & 15.4 & 2.79 & 9.0 & 78.0 \\
\hline
\end{tabular}

(a) Interval calculated by the calculated mean \pm 2 times the standard error and indicates with 95.5 confidence that the listed interval contains the true mean efficiency.

(b) Source: Hanson 1983.

(c) Source: BPA irrigation system audit program. 
TABLE 3.4. Calculated Students' $t$ Values and Significance Levels for Differences in Mean Pump Efficiencies Between Geographic Areas

\begin{tabular}{llccc}
\multicolumn{1}{c}{ Comparison } & \multicolumn{1}{c}{$\begin{array}{c}\text { Calculated } \\
\text { t Value }\end{array}$} & $\begin{array}{c}\text { Significance } \\
\text { Level }\end{array}$ \\
\cline { 1 - 1 } \cline { 5 - 5 } Oregon OWRI versus Idaho BPA & & 5.8 & & 0.001 \\
Oregon OWRI versus Oregon BPA & & 2.1 & & 0.05 \\
Oregon OWRI versus Washington BPA & & -8.4 & & 0.001 \\
Oregon OWRI versus W. Montana BPA & & 15.5 & & 0.001 \\
Idaho BPA versus Oregon BPA & & -1.2 & & 0.3 \\
Idaho BPA versus Washington BPA & & -7.3 & & 0.001 \\
Idaho BPA versus W. Montana BPA & & 2.2 & & 0.05 \\
Oregon BPA versus Washington BPA & & -2.7 & & 0.01 \\
Oregon BPA versus W. Montana BPA & & 4.7 & & 0.001 \\
Washington BPA versus W. Montana BPA & & 14.7 & & 0.001
\end{tabular}

difference between the mean efficiencies of the Oregon-OWRI data and the Oregon-BPA data was less significant than for all of the other comparisons.

In summary, this assessment of pumping plant efficiency based on data from 1,134 pump tests indicates that pumping plant efficiency varies considerably among pumping plants. The 1,134 pumping plants from locations throughout the Northwest have a mean efficiency of $57.3 \%$. Examination of the pumping plant test data at the subregional level indicates that differences between the mean efficiencies calculated for each of four major subregions of the Northwest are generally significant. Western Montana has the lowest mean pumping plant efficiency, followed by Idaho, Oregon, and Washington in order of increasing mean efficiency. The next chapter addresses pumping plant characteristics from a number of perspectives including; (a) component contributions to pumping plant efficiency, (b) influences on efficiency of total operating head and plant size, and $(c)$ the number of hours that pumping plants are operated during the irrigation season. 


\subsection{CHARACTERISTICS OF IRRIGATION MDTORS, PUMPS, AND PUMPING PLANTS}

In this chapter, specific components (i.e., motors and pumps) of pumping plants are singled out for their contribution to pumping plant inefficiencies. In addition, total operating head and pumping plant horsepower are examined to see if there is relationship between these two characteristics and plant efficiency.

\subsection{ELECTRIC MOTORS}

Even though the electrical motor is the final device that directly receives electrical power, its true function is to convert electrical energy to mechanical energy. The electric motor is quite efficient in this regard. Electric motors have the ability to convert from kilowatts of power input to the motor to horsepower of mechanical energy output at the motor shaft with only a small loss of energy in the process of conversion. The following information on electric motors is separated into information generally applicable to all electric motors and specific field data characterizing electric motors used within the region for irrigating crops.

\subsubsection{General Information on Motor Efficiency}

Electric motor efficiency is a measure of the motors ability to convert electrical energy to mechanical energy and can be expressed as:

$$
\text { Motor Efficiency }=\frac{746 \times \text { horsepower output }}{\text { watts input }} \times 100 \%
$$

where $1 \mathrm{hp}=746$ watts.

A more generic expression of efficiency is input energy minus energy losses during conversion divided by input energy. This expression, as shown in expression 4.2 , illustrates that the only way to improve the efficiency of a motor is to reduce losses in converting energy from electrical to mechanical. The energy an electric motor does not convert to mechanical energy during this process reverts to thermal energy, which eventually is dissipated to the environment. Because electric motors are generally efficient in converting 
energy from electrical to mechanical, the portion of energy that is directly converted to thermal and lost as heat is small. Even so, modest increases in motor efficiency could produce a measurable difference in the regional demand for electrical power by the irrigation sector.

$$
\text { Efficiency }=\frac{\text { Input }- \text { Losses }}{\text { Input }}
$$

Glenn (1983) reports that, since the early 1960s, electric motors, particularly those in the 1 to $250 \mathrm{hp}$ range, were designed for a minimum first cost. In some cases, motor efficiency suffered as the cost of materials used in the construction of electric motors was minimized. Glenn (1983) reports that the National Electrical Manufacturers Association (NEMA) has now adopted an efficiency standard for motors. The standard recognizes that the actual efficiency of motors manufactured to a given design can vary, but that the variation should be distributed normally around an average or mean. The mean and range can be established for each design. This approach recognizes that variations exist in materials, manufacturing processes, and testing of motor efficiency of a given design. Even for motors from the same manufacturer, the measured efficiency of individual motors can vary plus or minus $20 \%$ from the average. Figure 4.1 shows the expected distribution (characterized as a normal distribution) of motor efficiency around the average for all motors in that horsepower category.

Andreas' (1982) review addressed the average motor efficiency for standard motors. He notes that there is a defined mean efficiency within a horsepower size category and that individual motor efficiencies are distributed around the mean for the category. For example, a number of tests on 5 hp motors indicated that the average efficiency was $82 \%$ and that individual motors were found to have energy efficiencies ranging from 78 to $85 \%$ (Andreas 1982). Table 4.1 shows data reported by Glenn (1983) on the average efficiency and the range of efficiencies for motors in 19 hp categories. Average motor efficiency climbs from $82 \%$ for a 5 hp motor to $93 \%$ for a 200 hp motor. As shown in Table 4.1, average motor efficiencies for standard electric motors climb rapidly at lower levels of hp and more slowly at higher levels, especially for motors above 


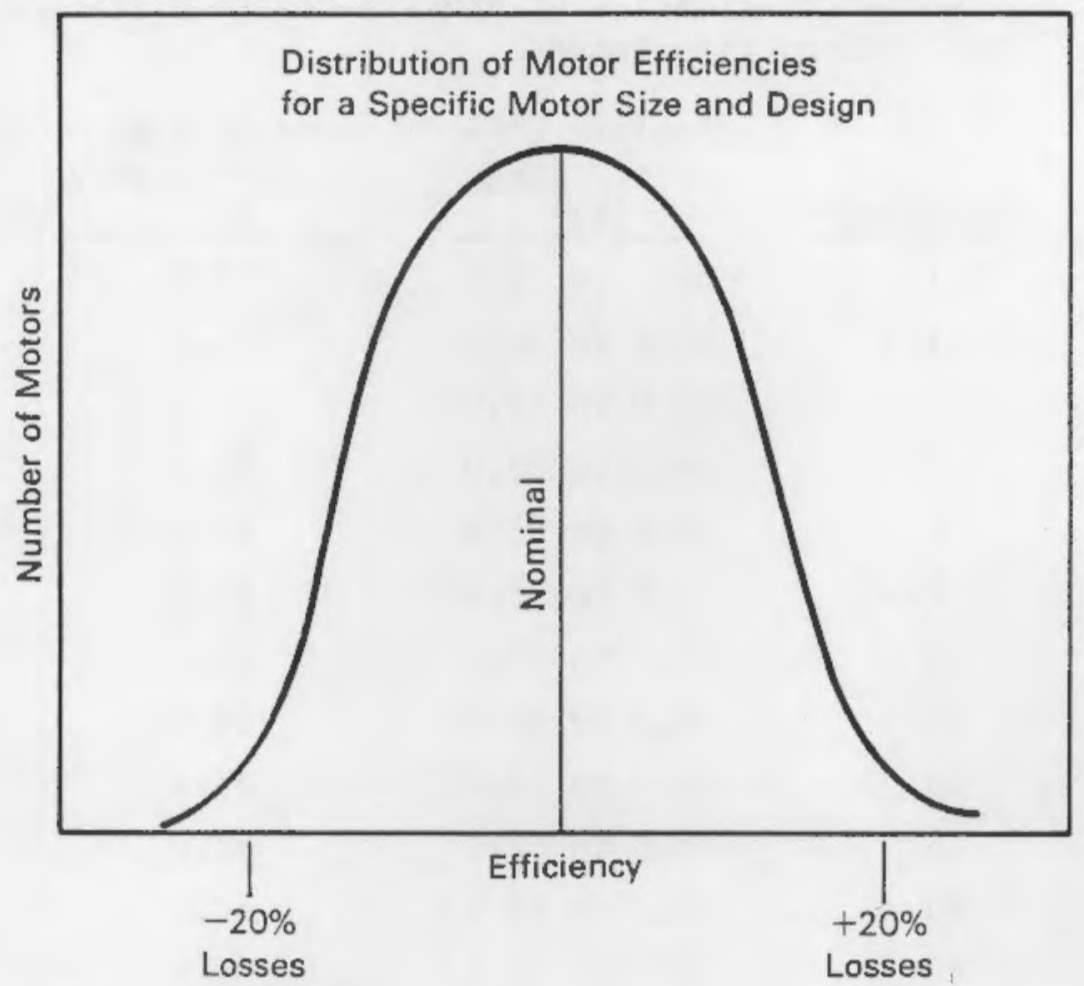

Source: Glenn 1981

\section{FIGURE 4.1. Motor Efficiency Distribution}

$75 \mathrm{hp}$. The average efficiencies and ranges are for new full-load motors of NEMA design B and standard three phase 1800 RPM induction motors.

A number of factors contribute to energy loss in electric motors. Keinz and Houlton (1981) note that typically, under no load conditions, from 5 to $10 \%$ of motor losses come from winding and friction losses. Core losses account for an additional 15 to $25 \%$ of the losses. Under load conditions stator resistance energy losses can account for 35 to $40 \%$, rotor resistance for 15 to $25 \%$, and stray load an additional 10 to $15 \%$. Stray losses are identified as being affected by; stator and rotor slot geometry, number of slots, air gap length, rotor slot insulation, and manufacturing processes (Keinz and Houlton 1981).

Besides motor characteristics, system parameters within the motor operating environment also influence overall motor efficiency. For example, motor operation at other than rated voltage and frequency can effect motor efficiency. Glenn (1983) notes that for a polyphase motor, a voltage inbalance of 
TABLE 4.1. Full-Load Efficiencies of NEMA(a) Design B Standard Three Phase 1800 RPM Induction Motors

\begin{tabular}{|c|c|c|}
\hline Horsepower & $\begin{array}{c}\text { Nominal Eff- } \\
\text { ciency Range } \\
(\%)\end{array}$ & $\begin{array}{l}\text { Average Nomi- } \\
\text { nal Efficiency } \\
(\%)\end{array}$ \\
\hline 1 & 68.0 to 78.0 & 73.0 \\
\hline 1.5 & 68.0 to 80.0 & 75.0 \\
\hline 2 & 72.0 to 81.0 & 77.0 \\
\hline 3 & 74.0 to 83.0 & 80.0 \\
\hline 5 & 78.0 to 85.0 & 82.0 \\
\hline 7.5 & 80.0 to 87.0 & 84.0 \\
\hline 10 & 81.0 to 88.0 & 85.0 \\
\hline 15 & 83.0 to 89.0 & 86.0 \\
\hline 20 & 84.0 to 89.0 & 87.5 \\
\hline 25 & 85.0 to 90.0 & 88.0 \\
\hline 30 & 86.0 to 90.5 & 88.5 \\
\hline 40 & 87.0 to 91.5 & 89.5 \\
\hline 50 & 88.0 to 92.0 & 90.0 \\
\hline 60 & 88.5 to 92.0 & 90.5 \\
\hline 75 & 89.0 to 92.5 & 91.0 \\
\hline 100 & 90.0 to 93.0 & 91.5 \\
\hline 125 & 90.5 to 93.0 & 92.0 \\
\hline 150 & 91.0 to 93.5 & 92.5 \\
\hline 200 & 91.5 to 94.0 & 93.0 \\
\hline $\begin{array}{l}\text { ource: Glen } \\
\text { (a) Nationa } \\
\text { Associa }\end{array}$ & $\begin{array}{l}83 . \\
\text { ectrical Mant }\end{array}$ & urers \\
\hline
\end{tabular}

$3.5 \%$ can increase motor losses about 15 to $20 \%$. In addition, changing motor load can be an important factor influencing motor losses.

To maintain low energy losses, motors should be operated between 75 and $100 \%$ of the rated load. Many motor manufacturers realize that a high percentage of all motors operate at between 75 and $80 \%$ of capacity and have designed motors to have their highest efficiency over this range (Glenn 1983). 


\subsubsection{Field Information on Motor Efficiency}

Little data on electric motor field operation is available to define the actual level of efficiency that electrical motors have while operating under load conditions within the agricultural environment. However, Hanson (1983) in his data set for Oregon irrigation pumping plants provides data on both the overall efficiency of individual pumping plants and the efficiency of the pump itself. Using this information, the efficiency of the electric motor component of the pumping plant was computed by dividing the overall pumping plant efficiency for a specific installation by the efficiency of that plant's pump. Enough pumping plant efficiency data and pump efficiency data was present to compute the field operating efficiency for 516 individual electrical motors. The 516 electric motors cover a wide range of motor sizes from 1 to $575 \mathrm{hp}$.

The arithmetic mean motor efficiency for the 516 electric motors is estimated to be $88.1 \%, \mp 0.3 \%$ at the $95.5 \%$ confidence level. Table 4.2 shows that

TABLE 4.2. Profile of Irrigation Motor Efficiency

\begin{tabular}{|c|c|c|c|}
\hline Efficiency (\%) & $\begin{array}{l}\text { Number of } \\
\text { Irrigation } \\
\text { Motors } \\
\end{array}$ & $\begin{array}{l}\text { Percent } \\
\text { of Total } \\
(\%) \\
\end{array}$ & $\begin{array}{c}\text { Cumulative } \\
\text { Percent } \\
\text { (\%) }\end{array}$ \\
\hline Less than 80 & 7 & 1.4 & 1.4 \\
\hline 80 to 83 & 26 & 5.0 & 6.4 \\
\hline 84 to 85 & 34 & 6.6 & 13.0 \\
\hline 86 & 35 & 6.8 & 19.8 \\
\hline 87 & 72 & 14.0 & 33.7 \\
\hline 88 & 96 & 18.6 & 52.3 \\
\hline 89 & 93 & 18.0 & 70.3 \\
\hline 90 & 54 & 10.5 & 80.8 \\
\hline 91 & 48 & 9.3 & 90.1 \\
\hline 92 & 34 & 6.6 & 96.7 \\
\hline 93 to 95 & 15 & 2.9 & 99.6 \\
\hline Over 95 & $\frac{2}{516}$ & 0.4 & 100.0 \\
\hline
\end{tabular}

Source: Hanson 1983. 
the efficiencies for individual motors appears to be distributed around the mean value of $88.1 \%$ in a pattern resembling a normal distribution. Of the 516 motors, 96 were found to have a motor efficiency of $88 \%$ while 93 motors had motor efficiencies of $89 \%$. Over two-thirds $(70.4 \%)$ of the motors have operating efficiencies between 87 and $92 \%$.

As indicated earlier in Table 4.1, motor efficiency varies with motor horsepower. The field operation data compiled from Hanson (1983) shows that this characteristic of electric motors continues to hold even after a number of years of operation within the agricultural environment. Motors were grouped into four categories according to horsepower (e.g. 0 to 25,26 to 50, 51 to 100 , and over $100 \mathrm{hp}$ ). Table 4.3 shows, for each category, the number of motors falling within the horsepower range of a category, the mean motor efficiency for motors in the category, the standard deviation for each category, and the minimum and maximum recorded motor efficiency. As shown in

Figure 4.2 , the field data reaffirms the assertion that even under agricultural field conditions, motor efficiency increases as motor size is increased. Computation of $t$ values for differences in mean efficiencies between size classes demonstrate that all differences shown are significant at a $0.001 \%$ level of confidence. Therefore, if all other pumping plant factors are equal, motor horsepower can influence the overall efficiency of a pumping plant by as much as $5 \%$.

TABLE 4.3. Motor Horsepower Versus Field Efficiency

\begin{tabular}{|c|c|c|c|c|c|}
\hline $\begin{array}{c}\text { Motor } \\
\text { Horsepower }\end{array}$ & $\begin{array}{l}\text { No. of } \\
\text { Units }\end{array}$ & $\begin{array}{c}\text { Mean } \\
\text { Efficiency } \\
(\%)\end{array}$ & $\begin{array}{l}\text { Std } \\
\text { Dev. }\end{array}$ & $\begin{array}{c}\text { Min } \\
\text { Value } \\
(\%)\end{array}$ & $\begin{array}{c}\operatorname{Max} \\
\text { Value } \\
(\%)\end{array}$ \\
\hline 0 to 25 & 260 & 86.7 & 2.35 & 75 & 93 \\
\hline 26 to 50 & 151 & 88.8 & 2.23 & 72 & 97 \\
\hline 51 to 100 & 67 & 90.3 & 3.28 & 70 & 93 \\
\hline Over 100 & 38 & 91.8 & 2.36 & 81 & 96 \\
\hline
\end{tabular}

Source: Hanson 1983. 


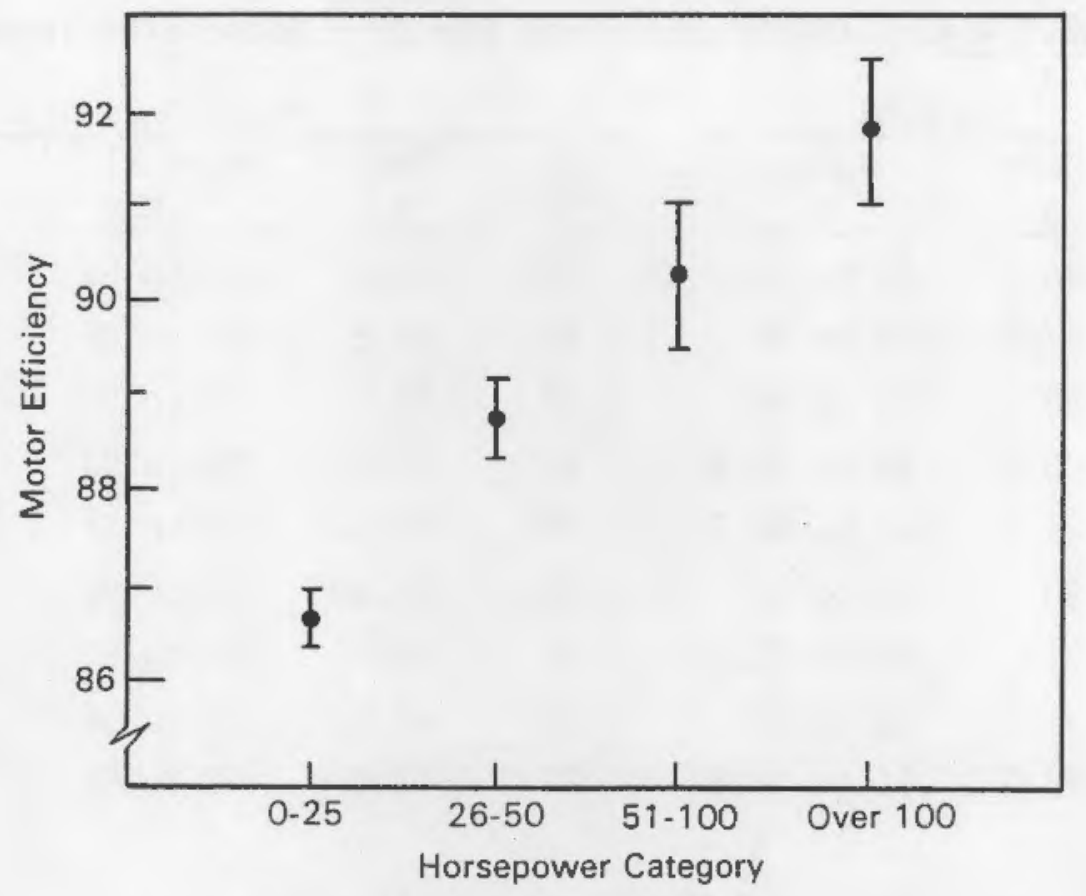

FIGURE 4.2. Motor Efficiency Versus Horsepower

A comparison of the motor efficiencies from the field data to efficiencies in the NEMA data (presented in Table 4.1) for 9 hp categories where the field data contained 20 or more motors is presented in Table 4.4. This table demonstrates that the mean motor efficiency in each $h p$ category for the field data is very close to the average efficiency data provided by NEMA. The largest difference between the NEMA data and the field data is at the 31- to 40-hp level where the difference between the two values is one percentage point, which is well within the range predicted by NEMA for this horsepower level.

The field data available to characterize electric motor efficiency indicates that electric motors tend to hold their efficiencies even after many years of field operation. Thus, for most electric motors used in irrigated agriculture, poor motor maintenance does not appear to be a major contributor to reduced pumping plant efficiency. Therefore, the principal method of improving irrigation pumping plant electric motor efficiency is to place highefficiency electric motors in these plants. Once high-efficiency motors are placed into irrigation pumping plants it appears that the energy savings from such motors could be counted on for many years into the future. 
TABLE 4.4. NEMA $(a)$ and Field Electric Motor Efficiency

\begin{tabular}{|c|c|c|c|c|c|c|c|}
\hline \multirow[b]{2}{*}{$\begin{array}{c}\text { Motor } \\
\text { Horsepower }\end{array}$} & \multicolumn{2}{|c|}{ NEMA } & \multicolumn{5}{|c|}{ Field Data } \\
\hline & $\begin{array}{l}\text { Mean } \\
\% \\
\end{array}$ & $\begin{array}{c}\text { Range } \\
\%\end{array}$ & $n^{(b)}$ & $\begin{array}{l}\text { Mean } \\
\% \\
\end{array}$ & $\begin{array}{c}\text { Interval(c) } \\
\% \\
\end{array}$ & $\begin{array}{c}\text { Min } \\
\% \\
\end{array}$ & $\begin{array}{c}\operatorname{Max} \\
\% \\
\end{array}$ \\
\hline 0 to 15 & 86 & 83 to 89 & 55 & 86.3 & 83 to 89 & 81 & 89 \\
\hline 16 to 20 & 87.5 & 84 to 89 & 56 & 87.5 & 86 to 89 & 86 & 90 \\
\hline 21 to 25 & 88 & 85 to 90 & 80 & 88.1 & 86 to 90 & 86 & 93 \\
\hline 26 to 30 & 88.5 & 86 to 90.5 & 61 & 88.3 & 84 to 93 & 78 & 97 \\
\hline 31 to 40 & 89.5 & 87 to 91.5 & 46 & 88.5 & 83 to 94 & 72 & 91 \\
\hline 41 to 50 & 90 & 88 to 92 & 41 & 89.6 & 88 to 91 & 87 & 91 \\
\hline 51 to 75 & 91 & 89 to 92.5 & 21 & 90.2 & 84 to 97 & 76 & 92 \\
\hline 76 to 100 & 91.5 & 90 to 93 & 26 & 91.2 & 88 to 94 & 87 & 93 \\
\hline 101 to 150 & 92.5 & 91 to 93.5 & 20 & 92.2 & 90 to 95 & 91 & 96 \\
\hline
\end{tabular}

(a) NEMA = National Electrical Manufacturers Association

(b) $n=$ number of motors.

(c) Calculated confidence interval based on \pm two standard errors about the mean.

\subsection{IRRIGATION PUMPS}

Like motors, irrigation pumps that pressurize water and move it from its source through the application system come in horsepower sizes that vary from one to several hundred horsepower. At a given rotation speed, a centrifugal pump will operate at peak efficiency only under certain conditions of flow rate and pressure. These conditions are determined by the pump's design. The efficiency of a centrifugal pump may be as high as $90 \%$ under laboratory conditions or as $10 w$ as $10 \%$ under the worst of conditions. Commercially available pumps for agricultural irrigation generally have efficiencies that range from 75 to 85\% (Hanson 1983). Information for characterizing a pump for flow rate, pres sure and efficiency is usually provided by manufacturers to facilitate the selection of a pump that correctly matches the operational needs of an irrigation pumping system. The information available about a specific pump is generally developed under laboratory or bench test conditions. 
Very little information is available about the actual efficiency of an individual pump after it is placed in a pumping plant and operated under field conditions. The major obstacle to measuring the actual efficiency of pumps after they are placed in a pumping plant is that the pump itself needs to be connected to other water delivery components to deliver water from the water source to the pump discharge. In some cases the intake, discharge and drive configurations used in this delivery system have only a small impact on the measured pump efficiency. In these cases, the actual pump efficiency is close to the pump efficiency calculated using Equation 4.3. In other cases, the intake, discharge, and drive components have a pronounced impact on what efficiency is measured and described as pump efficiency. For example, column and drive line energy losses in wells may reduce measured pump efficiency by $5 \%$ or more (Hamrick 1980).

$$
\text { Pump Efficiency }=\frac{\text { Pumping Plant Efficiency }}{\text { Motor Efficiency }} \times 100
$$

Using Equation 4.3, Hanson (1983) calculated pump efficiencies based on Oregon pump test data. These pumps include both small and large horsepower pumps, low and high total operating heads, and pumps classified as centrifugal and turbine. The calculated mean pump efficiency from the data set of 516 pumps is $65.1 \%$. As mentioned above, this calculated value for pump efficiency includes inefficiencies associated with the plumbing of the pumping plant. These inefficiencies are not distinguishable from pump efficiency under normal wire-to-water methods of testing pumping plant efficiency. Thus, both factors (pump efficiency and plumbing inefficiencies) are combined into one single value in characterizing pump efficiency under field operating conditions.

Pump efficiencies identified in the Oregon data set range from a minimum recorded efficiency of $16 \%$ to a maximum recorded efficiency of $89 \%$. Calculation of two standard errors for the mean of the 516 pumps suggests that if the sample is representative, the actual mean pump efficiency for Oregon pumps lies between 64 and $66 \%$ at a 95.5 level of confidence. The field observation of pump efficiency is well below the 75 to $85 \%$ efficiency generally indicated for 
new pumps under bench test conditions. This difference in pump efficiency sug.* gests that up to $10 \%$ points of efficiency may be lost due to energy losses in the intake and discharge plumbing; pump impeller and bow 1 wear; differences in impeller and bowl polish between bench tested and field operated pumps; and one of the most important factors--operation of pumps under flow and pressure conditions which are outside the design conditions that define the pumps' maximum efficiencies.

The energy efficiency profile for 516 Oregon pumps is shown in Table 4.5 . As noted in Table 4.5, approximately one-third of the pumps have pump pump efficiencies of $60 \%$ or less and nearly one-half of the pumps have efficiencies of $65 \%$ or less. About $12 \%$ of the pumps are identified as operating at efficiencies below $50 \%$.

To determine whether a relationship exists between pump efficiency and pump size, the pump efficiency data for each of the 516 pumps were placed in one of seven horsepower categories. The mean efficiency and other statistical

TABLE 4.5. Energy Efficiency Profile for 516 Oregon Irrigation Pumps

\begin{tabular}{lccc} 
Efficiency (\%) & $\begin{array}{c}\text { No. of } \\
\text { Pumps }\end{array}$ & $\begin{array}{c}\text { Percent } \\
\text { of Total } \\
(\%)\end{array}$ & $\begin{array}{c}\text { Cumulative } \\
\text { Percent } \\
(\%)\end{array}$ \\
\hline 540 & 18 & 3.5 & 3.5 \\
41 to 45 & 19 & 3.7 & 7.2 \\
46 to 50 & 24 & 4.7 & 11.8 \\
51 to 55 & 68 & 7.4 & 19.2 \\
56 to 60 & 82 & 15.9 & 32.4 \\
61 to 65 & 77 & 14.9 & 48.3 \\
66 to 70 & 87 & 16.9 & 63.2 \\
71 to 75 & 64 & 12.4 & 80.0 \\
76 to 80 & 29 & 5.6 & 92.4 \\
81 to 85 & 10 & 1.9 & 98.1 \\
0ver 80 & 516 & & 100.0
\end{tabular}

Source: Hanson 1983. 
measures were calculated for this data. Table 4.6 shows the results of this examination. Note that in Table 4.6 the number of observations is highly weighted toward the smaller horsepower categories. Table 4.6 indicates that, under field operating conditions, pump efficiency remains relatively constant with pump size for pumps below $150 \mathrm{hp}$. Above $150 \mathrm{hp}$, the number of observations in this data is too small to establish any relationship between pump efficiency and pump size.

The Oregon data set of 516 pumps included data on 404 individual centrifugal pumps and 71 individual turbine pumps. Another 41 pumping plants consisted of two or more pumps and are not used in comparing the efficiencies of the two types of pumps. The mean pump efficiency for the centrifugal pumps is estimated to be approximately $65.9 \%$ while the mean for the turbine pumps is estimated to be approximately $61.8 \%$ as shown in Table 4.7 . This difference is statistically significant at a 0.001 level of confidence, and indicates that irrigation pump efficiencies are generally lower for turbine pumps (predominately used to pump groundwater) than for centrifugal pumps (predominately used to pump surface water). Table 4.7 also shows the number of pumps within

TABLE 4.6. Pump Horsepower Versus Pump Efficiency in Oregon Irrigation Pumping Plants

\begin{tabular}{|c|c|c|c|c|c|c|c|}
\hline \multirow[b]{2}{*}{ Pump (hp) } & \multicolumn{3}{|c|}{ Arithmetic Mean } & \multirow[b]{2}{*}{$\begin{array}{l}\text { Std } \\
\text { Dev. }\end{array}$} & \multirow[b]{2}{*}{$\begin{array}{l}\text { Std } \\
\text { Error } \\
\end{array}$} & \multirow[b]{2}{*}{$\underline{(\%)}$} & \multirow[b]{2}{*}{$(\%)$} \\
\hline & $\begin{array}{l}\text { No. of } \\
\text { Units }\end{array}$ & $\begin{array}{r}\text { Mean } \\
(\%) \\
\end{array}$ & $\begin{array}{c}\text { Interva] } \\
(\%) \\
\end{array}$ & & & & \\
\hline 0 to 25 & 260 & 64.8 & 63.3 to 66.3 & 12.2 & 0.755 & 24 & 89 \\
\hline 26 to 50 & 151 & 65.6 & 63.8 to 67.4 & 11.3 & 0.92 & 16 & 87 \\
\hline 51 to 100 & 67 & 65.4 & 62.2 to 68.6 & 12.9 & 1.575 & 38 & 89 \\
\hline 101 to 150 & 27 & 62.9 & 58.0 to 67.8 & 12.8 & 2.465 & 33 & 85 \\
\hline 151 to 250 & 6 & 61.3 & NA & NA & NA & NA & NA \\
\hline 251 to 500 & 4 & 68.5 & NA & NA & NA & NA & NA \\
\hline Over 500 & 1 & 81.0 & NA & NA & NA & NA & NA \\
\hline Al1 & 516 & 65.1 & 64.0 to 66.2 & 12.0 & 0.53 & 16 & 89 \\
\hline
\end{tabular}

(a) Calculated at plus or minus two standard errors about the mean. $N A=$ Not applicable (less than 20 units).

Source: Hanson (1983). 
TABLE 4.7. Centrifugal Versus Turbine Pump Efficiency in Oregon Irrigation Pumping Plants

\begin{tabular}{|c|c|c|c|c|c|c|c|}
\hline \multirow{2}{*}{ Pump (hp) } & \multirow[b]{2}{*}{$\begin{array}{l}\text { No. of } \\
\text { Units } \\
\end{array}$} & \multicolumn{6}{|c|}{ Pump Efficiency } \\
\hline & & $\begin{array}{r}\text { Mean } \\
(\%) \\
\end{array}$ & $\begin{array}{c}\text { Range } \\
(\%)\end{array}$ & $\begin{array}{l}\text { Std } \\
\text { Dev. }\end{array}$ & $\begin{array}{l}\text { Std } \\
\text { Error }\end{array}$ & $\begin{array}{l}\text { Min } \\
(\%) \\
\end{array}$ & $\begin{array}{l}\operatorname{Max} \\
(\%)\end{array}$ \\
\hline \multicolumn{8}{|c|}{ Centrifugal Pumps } \\
\hline 0 to 25 & 233 & 65.7 & 64.2 to 67.3 & 11.8 & 1.55 & 24 & 89 \\
\hline 26 to 50 & 134 & 65.4 & 63.5 to 67.4 & 11.3 & 1.95 & 16 & 87 \\
\hline 51 to 100 & 30 & 68.1 & 63.2 to 73.0 & 13.3 & 4.86 & 40 & 89 \\
\hline 101 to 150 & 7 & 74.6 & NA & NA & NA & NA & NA \\
\hline 151 to 250 & -- & -- & -- & -- & -- & -- & -- \\
\hline 251 to 500 & $\rightarrow$ & -- & -- & -- & --- & -- & $\rightarrow$ \\
\hline Over 500 & $=$ & -- & $=$ & $\underline{--}$ & $=-$ & $=$ & $\underline{-}$ \\
\hline Total & 404 & 65.9 & 64.7 to 67.1 & 11.7 & 1.16 & 16 & 89 \\
\hline \multicolumn{8}{|l|}{ Turbine } \\
\hline 0 to 25 & 14 & 54.6 & NA & NA & NA & NA & NA \\
\hline 26 to 50 & 9 & 69.2 & NA & NA & NA & NA & NA \\
\hline 51 to 100 & 22 & 64.5 & 58.9 to 70.1 & 13.1 & 5.6 & 38 & 82 \\
\hline 101 to 150 & 18 & 60.0 & NA & NA & NA & NA & NA \\
\hline 151 to 250 & 6 & 61.3 & NA & NA & NA & NA & NA \\
\hline 251 to 500 & 2 & 67.5 & NA & NA & NA & NA & NA \\
\hline Over 500 & $=$ & - & $=$ & $=$ & -- & - & $\approx$ \\
\hline Total & 71 & 61.8 & 58.1 to 65.5 & 15.7 & 3.7 & 24 & 78 \\
\hline
\end{tabular}

$N A=$ Not Applicable (less than 2D units).

each of the eight horsepower categories, and associated statistical values for each category with more than 20 observations.

As expected, examination of pumps at the centrifugat pump and turbine pump level of detail does not dispute the findings discussed in the previous section (e.g. under field operating conditions pump efficiency remains relatively constant with pump size for pumps below $150 \mathrm{hp}$ ). 


\subsection{PUMPING PLANTS}

In this section, pumping plants are characterized in terms of total operating head, pumping plant size, and pumping plant efficiency.

\subsubsection{Total Operating Head Versus Plant Efficiency}

The amount of pressure an irrigation pump must supply to move water from its source through the application system is referred to in a number of ways including "total operating head, "total dynamic head," or "head." Total operating head is used in this discussion and is the sum of the elevation, velocity, pressure, and friction losses between the supply water and the discharge water. Thus, total operating head is defined as follows:

$$
\text { Total Operating Head }=h_{p}+h_{e}+h_{v}+h_{1}
$$

Total operating head is usually expressed in feet. Pressure head $\left(h_{p}\right)$ is the height to which water would be raised by a given pressure, $\left(h_{e}\right)$ is the change in elevation of water between the water source and the point of discharge, $\left(h_{v}\right)$ is the height to which water can rise as a consequence of its kinetic energy, and $\left(h_{1}\right)$ is the head loss due to friction/turbulence in pipes, valves, and fittings.

Data from the BPA and OWRI data sets includes pumping plants operating at total operating heads that ranged from below 75 feet to over 900 feet. The average operating head for all 1,134 pumping plants in the data sets is 214 feet. Table 4.8 shows a profile of pump operating head for these plants. Over one-third (35.6\%) of the pumping plants in the data set operate at pumping heads of 126 to 175 feet and almost $56 \%$ of the pumping plants operate between 126 and 225 feet.

Analysis of the relationship between total operating head and pumping plant efficiency shows a distinct relationship over three categories of total operating head. Only three pumping plants in the data set operate at heads below 25 feet, which is too few in number to be able to characterize plants in this category. The data set also includes 23 pumping plants with total operating head between 26 and 75 feet of pressure. However, since the variation in 
TABLE 4.8. Profile of the Total Operating Head for 516 Pumps

\begin{tabular}{lrcc}
$\begin{array}{c}\text { Operating } \\
\text { Head }\end{array}$ & $\begin{array}{c}\text { No. of } \\
\text { Units }\end{array}$ & $\begin{array}{c}\text { Percent } \\
\text { of Total } \\
(\%)\end{array}$ & $\begin{array}{c}\text { Cumulative } \\
\text { Percent } \\
(\%)\end{array}$ \\
\cline { 1 - 2 } & 3 & $\frac{0.3}{0.3}$ & $\frac{0.3}{6}$ \\
26 to 75 & 23 & 2.0 & 2.3 \\
76 to 125 & 177 & 15.6 & 17.9 \\
126 to 175 & 404 & 35.6 & 53.5 \\
176 to 225 & 249 & 22.0 & 75.5 \\
226 to 325 & 132 & 11.6 & 87.1 \\
326 to 500 & 59 & 5.2 & 92.3 \\
501 to 750 & 72 & 6.3 & 98.7 \\
Over 750 & 15 & 1.3 & 100.0
\end{tabular}

Source: BPA Irrigation System Audit Program; Hanson 1983.

pump plant efficiency is large and the number of plants small, the calculated standard error is high (3.3\%). Thus, for this category of total operating head, the mean for pumping plant efficiency is $45.3 \%$, but the mean could be as high as $52 \%$ or as low as $39 \%$ within a $95.5 \%$ confidence interval. The four categories of total operating head beginning with 25 to 50 feet and increasing to between 176 and 225 feet have mean efficiencies that are significantly different from one another.

The calculated means shown in Table 4.9 suggest that a positive relationship exists between total operating head and pumping plant efficiencies over the range of operating head from 26 to 225 feet. Pumping plants with operatins: heads above 225 feet have calculated mean efficiencies between 58 and $63 \%$ with no distinct improvement or decline in pumping plant efficiency as total operating head increases.

\subsubsection{Horsepower Versus Pumping Plant Efficiency}

Earlier in this report the relationship between motor horsepower and motor efficiency showed a definite positive relationship between electric motor size 
IABLE 4.9. Total Operating Head Versus Pumping Plant Efficiency

\begin{tabular}{|c|c|c|c|c|c|c|c|}
\hline \multirow{3}{*}{$\begin{array}{c}\text { Total } \\
\text { Operating } \\
\text { Head (ft) }\end{array}$} & \multirow[b]{3}{*}{$\begin{array}{l}\text { No. of } \\
\text { Units } \\
\end{array}$} & \multicolumn{6}{|c|}{ Pumping Plant Efficiency } \\
\hline & & \multicolumn{2}{|c|}{ Arithmetic Mean } & \multirow[b]{2}{*}{$\begin{array}{l}\text { Std } \\
\text { Dev. }\end{array}$} & \multirow[b]{2}{*}{$\begin{array}{l}\text { Std } \\
\text { Error }\end{array}$} & \multicolumn{2}{|c|}{ Range } \\
\hline & & $\begin{array}{l}\text { Mean } \\
(\%) \\
\end{array}$ & $\begin{array}{c}\text { Interval (a) } \\
(\%) \\
\end{array}$ & & & $\begin{array}{l}\operatorname{Min} \\
(\%) \\
(\%)\end{array}$ & $\begin{array}{l}\text { Max } \\
(\%) \\
\end{array}$ \\
\hline 0 to 25 & 3 & 28.7 & NA & 28.7 & NA & 9 & 50 \\
\hline 26 to 75 & 23 & 45.3 & 38.7 to 51.9 & 15.9 & 3.3 & 13 & 73 \\
\hline 76 to 125 & 177 & 49.6 & 47.7 to 51.5 & 12.6 & 0.95 & 9 & 77 \\
\hline 126 to 175 & 404 & 57.0 & 55.8 to 58.2 & 11.9 & 0.60 & 14 & 83 \\
\hline 176 to 225 & 249 & 60.9 & 59.5 to 62.3 & 11.1 & 0.70 & 11 & 83 \\
\hline 226 to 325 & 132 & 59.7 & 58.6 to 60.8 & 12.2 & 0.55 & 14 & 83 \\
\hline 326 to 500 & 59 & 62.0 & 59.0 to 65.0 & 11.7 & 1.5 & 37 & 79 \\
\hline 501 to 750 & 72 & 61.7 & 60.6 to 62.8 & 9.5 & 0.55 & 36 & 79 \\
\hline 751 to 1000 & 14 & 60.8 & NA & NA & NA & NA & NA \\
\hline
\end{tabular}

(a) Interval based on plus or minus two standard errors about the mean. $N A=$ Not Applicable (less than 20 units).

Source: BPA Irrigation System Audit Program; Hanson 1983.

and electric motor efficiency. In this section, field data is examined to determine if a relationship exists between pumping plant size and pumping plant efficiency. As before, the pumping plant is defined as including an electric motor, a pump, intake and discharge plumbing, and pumping plant valves and fittings.

The data set of 1,134 pumping plants includes a large number of pumping plants below $100 \mathrm{hp}$. Often pumping plants with 0 to $100 \mathrm{hp}$ are grouped into one category. In this examination, however, pumping plants below $100 \mathrm{hp}$ are divided into three horsepower categories, 0 to 25, 25 to 50, and 51 to 100. of the total 1,134 pumping plants, 933, or 82\%, have pumping plant horsepower ratings of $100 \mathrm{hp}$ or less. Seven categories of pumping plant horsepower are identified in Table 4.10. For each category, the number of plants and statistical values for plant efficiencies for all categories with more than 20 plants are shown in Table 4.10. 
TABLE 4.10. Pumping Plant Horsepower Versus Pumping Plant Efficiency

\begin{tabular}{|c|c|c|c|c|c|c|c|}
\hline \multirow{2}{*}{$\begin{array}{c}\text { Plant } \\
\text { Horsepower } \\
\end{array}$} & \multirow{2}{*}{$\begin{array}{l}\text { No. of } \\
\text { Units }\end{array}$} & \multicolumn{2}{|c|}{ Arithmetic Mean } & \multirow{2}{*}{$\begin{array}{l}\text { Std } \\
\text { Dev. }\end{array}$} & \multirow{2}{*}{$\begin{array}{l}\text { Std } \\
\text { Error } \\
\end{array}$} & \multicolumn{2}{|c|}{ Observed } \\
\hline & & Mean & Range & & & Min & Max \\
\hline 0 to 25 & 402 & 53.4 & 52.1 to 58.7 & 12.9 & 1.3 & 13 & 82 \\
\hline 26 to 50 & 322 & 57.4 & 56.1 to 58.7 & 11.5 & 1.3 & 9 & 83 \\
\hline 51 to 100 & 209 & 61.3 & 59.8 to 62.8 & 10.9 & 1.5 & 32 & 83 \\
\hline 101 to 150 & 80 & 62.2 & 59.2 to 65.2 & 13.2 & 3.0 & 11 & 80 \\
\hline 151 to 250 & 52 & 61.4 & 57.8 to 65.0 & 12.9 & 3.6 & 16 & 79 \\
\hline 251 to 500 & 63 & 58.2 & 54.7 to 61.7 & 13.9 & 3.5 & 9 & 81 \\
\hline Over 500 & 6 & 66.0 & NA & NA & NA & $\underline{N A}$ & NA \\
\hline Total & 1134 & 57.3 & 56.5 to 58.1 & 12.7 & 0.8 & 9 & 83 \\
\hline
\end{tabular}

Source: BPA Irrigation System Audit Program; Hanson 1983. $N A=$ Not Applicable (less than 20 units).

Over the first three categories of horsepower the mean pumping plant efficiencies increase from 53.4 to $61.3 \%$. The differences in mean efficiencies between categories of power plants up to $100 \mathrm{hp}$ are statistically significant. However, pumping plants above $100 \mathrm{hp}$ do not show a distinct improvement in pumping plant efficiency as hp is increased. It appears that increasing motor efficiency may be large enough to increase total pumping plant efficiency up to $100 \mathrm{hp}$, but beyond this point it is not able to produce a significant effect. As shown in Table 4.10, a11 categories, with the exception of pumping plants over $500 \mathrm{hp}$, (for which there are only six data points) have individual plants with very low and relatively high efficiencies.

The results regarding the relationship between pumping plant horsepower and plant efficiency are consistent with those for total operating head. In both cases, pump efficiency increased as total operating head and horsepower were increased up to specific limit beyond which future increases in efficiency were not found to occur. The consistency in results was to be expected, because previous studies have shown that irrigation pumping plant horsepower and measured total dynamic head are highly correlated (Harrer et al. 1987). 
The relationships between hp and plant efficiencies illustrated here and the size distribution of the 1,134 pumping plants indicates that the mean plant efficiency of $57.3 \%$ estimated in Chapter 3.0 is probably not representative of the regional plant efficiency. The addition of larger pumping plants in proportion to their population values would probably raise the calculated mean efficiency above $57.3 \%$. 


\subsection{LOW PUMPING PLANT EFFICIENCIES AND IRRIGATOR PERCEPTIONS}

This chapter sumarizes the information collected from pumping plant performance tests and from discussions with irrigation pumping plant specialists as to the reasons for low pumping plant efficiencies. The information presented in this chapter is divided into three sections. The first section reviews written information provided by BPA irrigation system auditors on pumps with comparatively low pumping plant efficiencies. The second section presents other published information and the results of conversations with knowledgable experts regarding the causes of low pumping plant efficiencies. The final section provides an analysis of irrigator perceptions of pumping plant efficiencies drawn from a recent survey of Pacific Northwest irrigators.

\subsection{BPA IRRIGATION SYSTEM AUDIT INFORMATION}

For purposes of obtaining an initial evaluation of the reasons for low pumping plant efficiencies, all pumping plants contained in the BPA irrigation system audit program with reported efficiencies of more than one standard deviation below the mean efficiency for a specific horsepower class were analyzed. These pumping plants were further divided into three classes as follows: 1.0 to 1.5 standard deviation below the mean efficiency; 1.5 to 2.0 standard deviation below the mean efficiency; and $>2.0$ standard deviations below the mean efficiency. The pumping plants that fell into these classes and the efficiency ranges represented by these classes are summarized in the Appendix.

Identification of the reasons for the relatively low pumping plant efficiencies involyed two steps:

- location of all available irrigation inspection forms and cover letters developed as part of the BPA irrigation system inspection program for all pumps falling into the three low efficiency classes

- examination of cover letters sent to each farmer concerning the completed pumping plant performance test and the pumping plant performance test data itself. 
The irrigation inspection forms and all of the primary data generated by the BPA irrigation system inspection program from 1982 to 1984 were sorted and analyzed. Inspection forms were located for approximately $80 \%$ of the irrigation pumping plants identified in the Appendix.

Examination of the selected inspection forms and cover letters developed by the irrigation system inspectors provided the results summarized in Table 5.1. Note from Table 5.1 that the most frequently mentioned cause of low pump efficiency was simply stated as a "worn pump or plugged impeller." In some cases, more specific information was provided on the specific areas of the pump that were worn (most frequently the rings or the impeller) but in general, such specific information was not provided. The second most frequently cited cause of low pump efficiency was "operating the pump at a lower flow rate than its optimal design flow rate even in the absence of significant pump wear." other causes of low pump efficiencies included air intake as a result of

TABLE 5.1. Causes of Low Irrigation Pumping Plant Efficiencies Ranked from Most Frequently Mentioned to Least Frequently Mentioned (a)

Frequency

Rank

1

2

3

4

5
Cause

Pump worn or plugged.

Flow rate lower than design flow rate even in the absence of significant pump wear.

Suction problems primarily caused by vortexing as a result of improper submergence.

Screen replacement or removal.

Debris in the pump inlet.

(a) Source: Unpublished data from BPA's irrigation system audits performed by FloSonics, Inc., Umatilla, Oregon, Donat and Associates, Post Falls, Idaho and others. 
improper pump submergence, sand filters and leaks in the pump. These causes were cited much less frequently than the causes of a worn pump or operating below the design flow rate.

In the majority of the pump test results presented in the irrigation inspection forms, the flow rate at which the pump was operating was significantly below the level where the pump's potential efficiency could be obtained. Thus, in most cases, changes in the pump that would increase efficiency would also increase pump flow rate. Without changes in the irrigators' irrigation scheduling, the energy savings from increasing pump efficiency could be negated by increased pump output.

The results of the analysis indicate the following:

- A significant number of irrigation pumping plants with energy efficiencies substantially below the mean efficiencies of pumping piants of a similar size are currently operating in the BPA service area

- The primary causes of these low pump efficiencies appear to be excessive pump wear and installation of pumps with larger flow rates than required to meet system needs.

It is noted that for many of the pumps identified in the Appendix, an assessment of the potential energy savings associated with the distribution and application components of the irrigation system could not be completed until the low pumping plant efficiency is corrected. Thus, estimation of the potential energy savings of conservation measures such as low-pressure systems and larger mainlines were not estimated in the system audit report. As a result, the existence of pumps with extremely low efficiencies hindered the analysis of the energy savings potential for the total irrigation system.

\subsection{MORE DETAILED INFORMATION}

Because the system audit information was unable to provide much detailed information on the causes of low pumping plant efficiencies, additional sources of information were collected and analyzed. 
Idaho Power conducted an irrigation pumping plant performance test program over a period of about four years. During the program, Bill Berry, Agricultural Engineer for Idaho Power reported, on the basis of 210 pumping plant tests, that there were five primary causes of low pumping plant efficiencies (Potato Grower of Idaho 1982):

1. Worn pumps--the example described pumping sand that wore the pumps

2. Wrong pump for the job--using larger pumps when smaller pumps would be more energy efficient and still do the job

3. Low pressure conversion without adapting pump

4. Groundwater table lowered so pump was taking in air

5. Pumps in a multiple pump bank not all built to operate at the same head--pumps not contributing their share of the water if they aren't built to operate at the same head.

Hugh Hanson in his report for the Dregon Water Resources Research Institute (1983) reports the following as the nine most common reasons for energy inefficiencies in irrigation pumping plants:

1. Improper pump selection

2. Poor selection of power plant

3. Improper well construction--cascading water and sand pumping

4. Improper or poorly installed pumping plants

5. Improper pump adjustment

6. Improper operating procedures

7. Inadequate pump maintenance

8. Inadequate well testing--unknown pumping levels

9. Changes in pumping head--altered system.

The following information concentrates on describing in more detail two of the major causes of poor pumping plant efficiency; badly worn pumps and improper pump size.

Worn Pumps

The leading reason for poor pump efficiency is excessive pump impeller and bowl wear. Pumping of fine sand particles is the most prominent factor in 
excessive pump wear. Sand particles moving through the system can be very abrasive. The pumping of sand erodes the pump impeller, the bowl, and can significantly widen the clearance between these two pump components. Once the clearance between impeller and bowt increases to 0.050 of an inch or more, pump efficiency begins to decline substantially. The pumping of considerable amounts of sand is possible from either wells or open ditches during just one irrigation season. Open ditch irrigation water can be so dirty that pumping plant intake screens 3 to 4 feet below the water surface can not be seen when looking into the water. (a) If an irrigation pump associated with a well or open ditch pumps $1,000 \mathrm{gpm}$ for 2,900 hours during one irrigation season, and the water pumped contains $20 \mathrm{ppm}$ of fine particulate sand, the pumping plant would move approximately 15 tons, or nearly 9 cubic feet, of sand (Helweg 1981).

Sand pumping from wells is a problem in some geographic areas and not in others. For example, in the area around Boise, Idaho, there are a number of wells that have sand pumping problems. It is not unusual for a purnp pumping large amounts of sand to require rebuilding within 3 to 4 years of its installation. Some pumps are pulled on an annual basis for inspection and repair.(b) In central and eastern Idaho, irrigation wells generally do not pump much sand, but this is not true for open ditch pumping where the surface water carries with it sand, seeds and other suspended particulates. (c)

The pumping of fine particulates is generally, but not always, detrimental to pump efficiency. In some cases, the pumping of fine grit actually polishes impeller blade and bowl surfaces increasing pumping plant pressure and flow. Thus, performance charts kept over a period of several years show an improvement in pumping plant flow for certain pumping plants. (d)

(a) Personal communication with Ralph Donat, Donat and Associates, Post Falls, Idaho, August 8, 1986.

(b) Personal comunication with Wayne Stevens, Wayne Stevens and Sons, Boise, Idaho, August 18, 1986.

(c) Personal communication with Howard Andrews, Andrews Well Drilling, Idaho Fal1s, Idaho, August 14, 1986.

(d) Personal communication with Barbara Henderson, FloSonics, Inc., Umatilla, Oregon, August 14, 1986. 
Other factors that can cause excessive pump wear are air pumping, incrustation, corrosion, rusting, or any combination of these factors. Air pumping can occur when gas bubbles form at points of low pressure and collapse under high pressure. An important outcome of air pumping is bowl cavitation and severe pump vibration. Cavitation can increases the roughness of metal surfaces while removing material. The severe vibration caused by cavitation can result in increased wear on pump parts. Air pumping can sometimes interfere with the flow of lubricants to the pumps' bearings thus reducing the life of the bearings. (a)

One source of the air that gets into the pumps is improper suhmergence of the intake structure allowing vortexes or eddies to bring air to the intake structure. In a number of cases where surface water is being pumped, the intake structure is close enough to the water surface that vortexes form bringing air directly to the intake structure and then to the pump. (b) A second reason for air pumping is that air is trapped in the water, (a) either as water cascades down the well in the case of well water, or because water is withdrawn from surface water sources such as streams where water velocities are relatively high. A third reason for pumping air is associated with suction lift. Here the pumping plant uses suction lift to bring water to the pump. However, if the portion of the pumping plants' intake pipe that is above the water line has cracks or pinholes, then air is brought into the pump along with the intake water. Cracks and pinholes can develop in the intake pipe especially where welds have been stressed in aluminum pipe. (c)

Incrustation, corrosion, and rust have also been mentioned by Helweg (1980) as factors that can damage pump components. For example, incrustation

(a) Personal communication with Howard Andrews, Andrews Well Drilling, Idaho Falls, Idaho, August 14, 1986.

(b) Personal communication with Ralph Donat, Donat and Associates, Post Falls, Idaho, August 8, 1986.

(c) Personal communication with Barbara Henderson, FloSonics, Inc., Umatilla, Oregon, August 15, 1986. 
from rust or other causes can build up on pump parts increasing friction, and thus reducing pump efficiency. Corrosion of impellers and bowls may increase wear and stress on pump parts.

Incrustation of well screens can reduce the overall efficiency of the pumping plant. Mineral incrustation of well screens is a problem in a few areas in the Northwest. (a) The introduction of acid treatment to the well, along with surging, can reduce incrustation formed on well screens and restore some of the lost efficiency due to flow restrictions. For pumping plants pumping from surface water sources, plugging of intake screens by debris is a common occurrence that restricts flow to these pumping plants. (b)(c)(d) Pumps sitting idle for long periods of time may deteriorate because no water is flowing through the pump to sweep away incrusted materials $(c)$ or because the bearings deteriorate. (b)

It has been the experience of some pumping plant specialists that what appeared to be a worn pump, at the time the pumping plant was performance tested, turned out to be debris located inside the pump when the pump was dismantled. Debris such as stones, beer cans, and small pieces of wood have been found inside pumps; this debris can reduce pumping plant efficiency significantly. (c)

Improper Pump Size

In many cases farmers are using larger pumps when smaller pumps would be more energy efficient and still meet their system requirements. Pump selection is a process of matching a pump with the specific characteristics of the water source and system requirements to deliver an appropriate rate and volume of water. Operating parameters define the proper pump to be selected and include the amount of water to be supplied, the location of delivery (elevation), and

\footnotetext{
(a) Personal communications with Paul Querna, Johnson Division, Redmond, Washington, April 28, 1986.

(b) Personal communication with Howard Andrews, Andrews Well Drilling, Idaho Falls, Idaho, August 14, 1986.

(c) Personal communication with Ralph Donat, Donat and Associates, Post Falls, Idaho, August 8, 1986.

(d) Personal communication with Barbara Henderson, FloSonics, Inc., Umatilla, Oregon, August 15, 1986.
} 
the discharge pressure. From the standpoint of energy efficiency, the desired pump discharge pressure and flow is where the pump achieves maximum efficiency-the design discharge that corresponds to the highest point on the pump efficiency curve. Often, apparently as a means of insuring adequate pres. sure and flow, irrigators select pumps with design discharges higher than wherf they actually operate. Thus, pump efficiency is reduced.

Other reasons for improper pump size include changes in operating conditions. Since a pump operates on a set of performance curves with specific characteristics for that particular pump, any change in the irrigation system requirements that causes overall changes in system flow or pressure may result in a change of where a pump operates on its pump curves. Thus, after initially operating on a high efficiency curve, a pump may Tater to forced to operate on a lower curve because of system flow or pressure changes. Specific examples of system changes that may lower pump efficiency include; hooking up additional sprinklers, pumping water to higher elevations, lowering water table, and reducing the application pressure for sprinkler irrigation. (a)(b)

Pumping plants that are operating at efficiencies well above typical efficiencies for a plant of their size are associated with irrigation systems that have been carefully designed to achieve high efficiency. (c) To achieve high overall system efficiency, it is important that pumping plant, delivery, and application systems are appropriately sized and designed so that agricultural crops are not over or under irrigated.

New Technology

Not much viable information on new pump technology was located during the conduct of this assessment although one pump manufacturer interviewed during this study stated that pumps with operating efficiencies above $80 \%$ are now

(a) Personal communications with Howard Andrews, Andrews Well Drilling, Idaho Falls, Idaho, August 14, 1986.

(b) Personal communications with Ralph Donat, Donat and Associates, Post Falls, Idaho, August 8, 1986.

(c) Personal communications with Barbara Henderson, FloSonics, Inc., Umatilla, Oregon, August 14, 1986. 
available in the commercial market, (a) no documentation supporting this claim was provided. It has also been suggested that pumps with enamel coated impellers and bowls be used in irrigated agriculture to reduce pump friction losses through improving the smoothness of the impeller and bowl. The enamel surface could aiso reduce accelerated wear due to sand pumping. (b) However, although this technology has previously been used in industrial applications, it has not been widely used in the irrigation environment. Thus, there is concern that the enamel will chip under harsh irrigation pumping conditions and lose its advantages in a relatively short time. (c) In addition, the cost of a pump having an enamel coated pumping surface may be as high as $50 \%$ above conventional pumps.

\section{Prevention of Low Pumping Plant Efficiencies}

The principal method of pumping water has not changed in years. In the Northwest, electric motors are used to turn either turbine or centrifugal pumps in irrigation pumping plants. Proper design of the pumping plant, including selection of the appropriate motor and pump, is essential to good pumping plant efficiency. Continued maintenance is also necessary to maintain high levels of efficiency, including at least seasonal inspections of pumping plant components.

Farmers pumping irrigation water from surface water sources have the advantage that, in many cases, they can take the pump apart for inspection in less than an hour without a great deal of costs. Farmers with high electrical energy charges may be particularly interested in inspecting their pumps on an annual basis. The inspection would remove any debris lodged in the pump and would reveal if excessive pump wear is present. The farmer could then decide if repair work needed to be done to the pump, providing he had good information

\footnotetext{
(a) Personal communications with Richard Screen, Cornell Pump Co., Portland, Oregon, April 4, 1986.

(b) Personal communications with Ralph Donat, Donat and Associates, Post Falls, Idaho, August $8,1986$.

(c) Personal communications with Barbara Henderson, FloSonics, Inc., Umatilla, Oregon, August 14, 1986.
} 
on the costs and benefits of repair. Groundwater pumping plants are much more expensive to inspect because of the high pulling costs associated with obtaining access to the pump.

Improvements in pumping plant inspection, maintenance, and design appear to be the key ingredients for improving pumping plant efficiencies. However, the lifetimes of many of the measures that could be used to improve irrigation pumping plant efficiencies may be too short for them to be considered viable long-term conservation resources. Quantifying the potential energy savings of such actions as improved pump maintenance would also appear to be a complex task that likely is not warranted.

Another promising and less "information intensive" method may be through the use of high-efficiency motors. Although the technology for high-efficiency electric motors is not entirely new, the costs of electric power now encourages the design, production, and marketing of such motors. A more detalled discussion of high-efficiency motors and their potential energy savings is provided in Chapter 6 .

\subsection{IRRIGATOR PERCEPTIONS OF PUMPING PLANT EFFICIENCIES}

Information provided to date in this report has analyzed the results of irrigation pumping plant efficiency field tests and the potential causes of low pumping plant efficiencies. This section of the report summarizes the results of a telephone survey of Pacific Northwest irrigation customers (a) that incorporated several questions regarding irrigation pumping plant efficiencies. It will provide a prospective on irrigator perceptions of the efficiencies of their pumping plants that could be useful in designing programs to potentialiy improve these efficiencies.

In the telephone survey, irrigators were asked a series of seven questiors, related to their irrigation pumping plant efficiencies. The 1,244 respondents in the survey provided information regarding whether they had a pump test, what.

(a) The survey from which these results are drawn included 1,244 valid responses from irrigators selected using stratified random sampling methods. These methods are described in detail in a related report (Harrer 1986a). 
they thought their existing pumping plant efficiency was, and other information. These responses were then statistically weighted based on the population of irrigation customers with irrigation load characteristics similar to the respondent ${ }^{(a)}$ to derive estimates of regional population values for selected variables.

The first major point to note from the results of the survey is that most irrigators do not know the level of the energy efficiency of their pumping plants. An estimated $53 \%$ of regional irrigators responded "don't know" when asked the question "What is the current average pumping plant efficiency of pumps operating on your farm?" Approximately $46 \%$ provided an estimate and $1 \%$ refused.

The second major point to note from the survey results is that irrigators believe that their pumping plant efficiencies are significantly higher than they actually are based on field tests. This point is illustrated by information presented in Table 5.2, which presents mean estimates (for those providing estimates) to the question regarding current average pumping plant efficiencies of pumps operating on irrigators' farms. The information presented in Table 5.2 is summarized by the usage size classification of the respondents. A key for this classification is provided at the bottom of the table.

The mean estimated population response of $76 \%$, presented in Table 5.2 , is significantly higher than the mean of $57 \%$ obtained from field test data. Differences in system characteristics between irrigation test program participants and survey respondents may account for some of the difference. However, it is believed that inaccurate irrigator perceptions regarding their pump efficiency levels likely account for most of the difference.

The point about inaccurate perceptions is further illustrated by the differences in responses among usage strata. Field test information presented in Chapter 4.0 illustrated that as pump horsepower was increased, pumping plant

(a) The weighting procedure is a complex "N factor" method of weighting that uses the number of customers in a defined usage class in a utility serving a specific geographic area as the basis for weight construction. It is described in detail in a related report (Harrer 1986b). 
TABLE 5.2. Statistically Weighted Mean Pumping Plant Efficiencies by Usage Strata (a) Computed from Telephone Survey Results

\begin{tabular}{lc} 
Usage Strata & Weighted Mean \\
\hline 1 & 76 \\
2 & 79 \\
3 & 77 \\
4 & 76 \\
5 & 76 \\
6 & 78 \\
A11 Strata & 76 \\
& \\
\hline & \\
(a) Usage strata indicates the estimated \\
size of irrigators' electricity \\
demands, with Usage Strata 6 being \\
the largest demands comprised of al 1 \\
customers using more than 500 mega- \\
watt hours (MWh) in an irrigation \\
season. The other usage strata are \\
defined based on the five ranges of \\
MWh that comprise 20\% of the remain- \\
ing irrigation load after load in \\
Usage Strata 6 is subtracted out.
\end{tabular}

efficiency also increased up to a limit of $150 \mathrm{hp}$. However, the survey results presented in Table 5.2 illustrate that perceived levels of pumping plant efficiencies generally do not increase as the size of the respondent's irrigation load is increased. Thus, smaller irrigation customers appear to have greater misconceptions about their pumping plant efficiency levels than larger cust omers.

Irrigators were also asked in the survey whether or not they had had a pump test. An estimated $34 \%$ of regional irrigators responded affirmatively to this question. A frequency breakdown of the pump tests by year of the most recent test and by who performed the test is provided in Tables 5.3 and 5.4 . Note that the majority of those having a pump test reported having one within the last three years (64\%) and that utilities were reported as the major performer of pump tests $(34 \%)$. 
TABLE 5.3. Statistically Weighted Frequency Distribution for Year of Most Recent Pump Test

\begin{tabular}{lcr}
\multicolumn{1}{c}{ Year } & Frequency & Percent \\
\cline { 3 - 4 } Prior to 1980 & 459 & 5 \\
1980 & 816 & 9 \\
1981 & 955 & 10 \\
1982 & 890 & 9 \\
1983 & 737 & 8 \\
1984 & 1960 & 21 \\
1985 & 3276 & 35 \\
Don't Know & 355 & 4 \\
\multicolumn{1}{c}{ Total } & 9448 & 100
\end{tabular}

IABLE 5.4. Statistically Weighted Frequency Distribution of Irrigation Pumping Plant Tests by Performing Organization

\begin{tabular}{lrrr}
\multicolumn{1}{c}{ Performing Organization } & & Frequency & Percent \\
Self/farm hand & & 938 & 10 \\
Utility & 3187 & 34 \\
Consulting engineer & 188 & 2 \\
Irrigation district & 277 & 3 \\
College/university & 89 & 1 \\
Irrigation supply co./pump service contractor & 2485 & 26 \\
REA & 664 & 7 \\
Other & 1156 & 12 \\
Don't know & 466 & 5 \\
$\quad$ Total & & 9450 & 100
\end{tabular}

The performance of pump tests was found to have little impact on irrigator perceptions of their irrigation pumping plant efficiencies. This conclusion is illustrated by information provided in Table 5.5 on the results of the question on current average pumping plant efficiency segmented into those having a pump test and those not having a pump test. Note that there is almost no difference between those having a pump test and those not having a pump test in terms of 
TABLE 5.5. Segmentation of Information on Statistically weighted Current Average Pumping Plant Efficiency by Those Having a Pump Test Versus Those Not Having a Pump Test (Percent)

Proportion of irrigators providing efficiency estimate

Mean plant efficiency estimate

Proportion responding "don't know"

Proportion responding "refused"
Had Pump Test

45.3

77.0

53.2

1.5
Did Not $\frac{\text { Have Pump Test }}{46.6}$ 76.0 53.4 0.0

their ability or willingness to provide an estimate of their current average pumping plant efficiency. In addition, the mean efficiency estimate for irrigators willing to provide an estimate of pumping plant efficiency was almost identical for those having a pump test and those not having a pump test. The inadequacy of current irrigation pumping plant tests as a source of reliable information on pumping plant efficiencies is further illustrated by the fact that over $60 \%$ of those who had a pump test could not recall the reported efficiency on their most recent test. 


\subsection{REPLACEMENT EQUIPMENT}

In this chapter, one possible method of improving pumping plant efficiency is reviewed in more detail. The example chosen for detailed analysis is highefficiency electric motors. The potential energy savings for improving ali irrigation pumping plants to $65 \%$ efficiency are also estimated.

\subsection{ENERGY EFFICIENT MOTORS}

High-efficiency electric motors have the potential to produce electrical energy saving by reducing the internal electrical losses of electric motors. Improvements in energy efficiency can achieved by reducing resistance losses in both the stator and rotor windings. In addition, friction losses in some of the mechanical parts of the motor can be reduced. Various material and design changes are employed in high-efficiency motors to reduce these losses. However, these changes are not standardized across all motors. Design changes employed in high-efficiency motors include the following (Hunt et a1. 1976):

- longer rotor and stator cores that reduce the density for the electro-magnetic field of the motor and increase the conductivity of the rotor and stator to electrical input

- thinner rotor and stator cores that reduce the amount of current lost. through the outside of the rotor and stator

- use of silicon steel rather than carbon steel in rotor and stator cores to reduce the amount of energy lost in the creation of the electromagnetic field.

High-efficiency motors can be operated in the same manner as standard electric motors and can be expected to have operating lifetimes equal to those of standard motors. However, a large amount of higher quality materials are required for manufacturing high-efficiency motors, which increases their initial purchase cost (Hane et al. 1983). Thus, a potential purchaser of a 
high-efficiency motor is faced with determining whether the electricity cost savings of the motor will be sufficient to justify a higher initial purchase price (Moe et al. 1986).

High-efficiency electric motors have been available in the marketplace for a number of years. Many of the major electric motor manufacturers produce high-efficiency motors so commercial high-efficiency motors are widely available. Normally, manufacturers offer both standard and high-efficiency motors in a variety of sizes. Motors with the nominal efficiency values shown in Table 6.1 or higher are generally considered to be in the high-efficiency motors category.

TABLE 6.1. High Efficiency Motors

\begin{tabular}{ccc}
$\begin{array}{c}\text { Motor } \\
\text { Horsepower }\end{array}$ & $\begin{array}{c}\text { Minimum } \\
\text { Average } \\
\text { Nominal } \\
\text { Efficiency } \\
(\%)\end{array}$ \\
\cline { 1 - 1 } 7.5 & & 88.0 \\
10 & & 88.6 \\
15 & & 90.0 \\
20 & & 90.7 \\
25 & & 91.2 \\
30 & & 91.7 \\
40 & & 92.2 \\
50 & 92.6 \\
60 & 93.0 \\
75 & 93.4 \\
100 & 93.7 \\
125 & 94.0 \\
150 & 95.0 \\
200 & 95.4
\end{tabular}


In order to derive an estimate of the potential energy savings of highefficiency electric motors, a sample of billing data collected in association with a PNL survey of irrigators was used. For purposes of this study, singlemeter billing data from nine utilities(a) comprising approximately $20 \%$ of Pacific Northwest regional irrigation load was incorporated in the estimation procedure. This data contained 4,865 observations on the metered consumption of electricity by irrigation pumping plants and it is understood that each meter represented a single pumping piant in at least $90 \%$ of the observations.

The potential energy savings available by replacing all 4,865 electric motors in the sample with high-efficiency electric motors are shown in Table 6.2. The table shows the 1984 seasonal electrical use of all pumping plants by utility horsepower category. The estimated difference between the

TABLE 6.2. Potential Electrical Energy Savings for a Sample of Replacing 4,865 Pumping Plant Electric Motors with High-Efficiency Motors

\begin{tabular}{|c|c|c|c|c|}
\hline $\begin{array}{c}\text { Motor Size } \\
\text { Electrical } \\
\text { (hp) } \\
\end{array}$ & $\begin{array}{l}\text { Number } \\
\text { of Plants }\end{array}$ & $\begin{array}{l}\text { Seasonal } \\
\text { Use (MWh) }\end{array}$ & $\begin{array}{l}\text { Approximate } \\
\text { Difference Between } \\
\text { High-Efficiency }(a) \\
\text { Standard Motor }(\%) \\
\end{array}$ & $\begin{array}{c}\text { Maximum } \\
\text { Potential } \\
\text { Potential } \\
\text { Savings (Mwh) } \\
\end{array}$ \\
\hline 0 to 5 & 438 & 2,400 & 14.0 & 336 \\
\hline 5 to 25 & 1,621 & 30,000 & 3.7 & 1,110 \\
\hline 25 to 50 & 1,207 & 50,800 & 3.0 & 1,524 \\
\hline 50 to 100 & 926 & 70,900 & 2.6 & 1,843 \\
\hline 100 to 150 & 320 & 39,200 & 2.5 & 980 \\
\hline 150 to 250 & 185 & 37,700 & 2.0 & 754 \\
\hline 250 to 500 & 130 & 56,200 & 2.0 & 1,124 \\
\hline$>500$ & 38 & 30,300 & $\underline{N A}(b)$ & NA \\
\hline Total & 4,865 & 317,500 & NA & 7,671 \\
\hline
\end{tabular}

(a) Source: Moe et al. 1986, The Electric Energy Savings from New Technologies, PNL-5665, Rev. 1 .

(a) Utilities included in the sample included Douglas County PUD, Grant County PUD, Harney Electric Coop., Lincoln Electric Coop., Oxanogan PUD, Surprise Valley Coop., Umatifla Electric Coop. and Wasco Electric Coop. 
motor efficiency of high-efficiency motors (Table 6.1) and existing field motors (Table 4.10) is used to estimate the percentage difference in energy use: between high-efficiency and standard motors shown in the fourth column of Table 6.2. The estimated megawatt hour energy savings from motor replacement are shown in the last column of Table 6.2. In this sample of pumping plants, it appears that electrical energy use by irrigation pumping plants could be reduced by approximately $2.4 \%$ if al1 4,865 electric motors were replaced with high-efficiency motors. This equates to a potential savings of approximately 96,000 MWh or 11 average MW if sample results are extrapolated to the region.

An analysis of the potential energy savings and costs of energy-efficient electric motors was also performed using the Irrigation Sector Energy Planning (ISEP) model. It was assumed based on the results of a previous study (Moe et al. 1986) that the the installation of energy efficient motors would produce an average gain in motor efficiency of three percentage points. It was also assumed, based on data from this previous study, that energy-efficient motors would cost approximately $\$ 865$ more than conventional motors. Thus, the incremental capital costs for an energy-efficient motor would be approximately $\$ 6.65$ per acre for a 130-acre field.

A summary of the results obtained from the ISEP model using the above assumptions is shown in Tables 6.3 to 6.5 . Note from Table 6.4 that the total estimated energy savings from energy-efficient motors on existing sprinkler acres is 10.75 average $\mathrm{MW}$, which is very close to the 11 average $M W$ estimated in Table 6.2. The additional savings on new sprinkler irrigated acres are estimated to be approximately 5.3 average MW.

Most (87\%) of the savings from energy-efficient electric motors could potentially be obtained for $25 \mathrm{mills}$ per $\mathrm{kWh}$ saved or less. The average incremental costs for obtaining energy savings from energy-efficient electric motors would generally be between 10 and $15 \mathrm{mills}$ per $\mathrm{kWh}$ saved, but these costs would vary significantly between groundwater and surface water installations.

Based on the results of this analysis, it appears that Bonneville may want to consider the addition of energy-efficient electric motors to its conservation resource profile. The potential estimated energy savings for energyefficient motors of 16.5 average MW by 2003 are larger than for improved 
TABLE 6.3. Potential Energy Savings (Average Megawatts) in 5-Mi11 Cost Increments for Energy-Efficient Electric Motors (a) on NewSprinkler Irrigated Acres in 2003

\begin{tabular}{|c|c|c|c|c|c|c|c|c|c|c|}
\hline \multirow{2}{*}{$\begin{array}{c}\text { Irrigation System/ } \\
\text { Acreage Type }\end{array}$} & \multicolumn{10}{|c|}{ Cost-Increment } \\
\hline & 5 & 10 & 15 & 20 & 25 & 30 & 35 & 40 & 45 & $5 \overline{0}$ \\
\hline $\begin{array}{l}\text { Center-Pivot Using } \\
\text { Surface Water }\end{array}$ & 0 & .02 & .03 & .12 & .27 & .40 & .52 & .52 & .52 & .52 \\
\hline $\begin{array}{l}\text { Center-Pivot Using } \\
\text { Ground Water }\end{array}$ & 0 & .16 & .53 & .55 & .59 & .59 & .59 & .59 & .59 & .59 \\
\hline $\begin{array}{l}\text { Handmove/Sideroll } \\
\text { Using Surface Water }\end{array}$ & 0 & .05 & .11 & .41 & .92 & 1.26 & 1.26 & 1.26 & 1.26 & 1.26 \\
\hline $\begin{array}{l}\text { Handmove/Sideroll } \\
\text { Using Groundwater }\end{array}$ & .44 & 1.28 & 2.74 & 2.78 & 2.80 & 2.87 & 2.94 & 2.97 & 2.97 & 2.97 \\
\hline $\begin{array}{l}\text { A1 } 1 \text { New-Sprinkler } \\
\text { Acres }\end{array}$ & .44 & 1.51 & 3.41 & 3.86 & 4.58 & 5.12 & 5.31 & 5.34 & 5.34 & 5.34 \\
\hline
\end{tabular}

TABLE 6.4. Potential Energy Savings (Average Megawatts) in 5-Mill Cost Increments for Energy-Efficient Motors $(a)$ on Existing Sprinkler Irrigated Acres

\begin{tabular}{|c|c|c|c|c|c|c|c|c|c|c|}
\hline \multirow{2}{*}{$\begin{array}{c}\text { Irrlgatlon System/ } \\
\text { Acreage Type }\end{array}$} & \multicolumn{10}{|c|}{ Cost-1 nerement } \\
\hline & 5 & 10 & 15 & 20 & 25 & 30 & 35 & $40^{\circ}$ & 45 & 50 \\
\hline $\begin{array}{l}\text { Center-Pivot Using } \\
\text { Surface Water }\end{array}$ & 0 & .15 & .23 & .32 & .49 & .62 & .80 & .80 & .81 & .81 \\
\hline $\begin{array}{l}\text { Center-PIvot UsIng } \\
\text { Groundwater }\end{array}$ & .46 & 2.36 & 2.74 & 2.76 & 2.82 & 2.88 & 2.88 & 2.88 & 2.88 & 2.88 \\
\hline $\begin{array}{l}\text { Handmove/Siderol I } \\
\text { Using Surtace Water }\end{array}$ & 0 & .38 & .46 & 1.13 & 1.72 & 2.42 & 2.53 & 2.62 & 2.65 & 2.65 \\
\hline $\begin{array}{l}\text { Handmove/Si derol1 } \\
\text { Using Groundwater }\end{array}$ & .27 & 3.58 & 3.92 & 4.29 & 4.33 & 4.33 & 4.35 & 4.37 & 4.37 & 4.41 \\
\hline $\begin{array}{l}\text { All Exlsting Sprinkler } \\
\text { Acres }\end{array}$ & .73 & 6.47 & 7.35 & B. 50 & 9.36 & 10.25 & 10.56 & 10.67 & 10.71 & 10.75 \\
\hline
\end{tabular}
(a) All costs and energy savings represent Incremental costs and energy savings
compared to o standard efficlency electric mofor.

fittings design and these savings could generally be obtained for 25 mills per kWh saved or less. However, the market penetration of energy-efficient motors is likely to be very slow, because it is only economically justifiable to purchase and install such motors at the time when a conventional motor is replaced because it has worn out. 
TABLE 6.5 Average Levelized Cost Per kWh Saved (Mills) for EnergyEfficient Motors

\begin{abstract}
Efflciency Improvement on Center-PIvot

Efficiency Improvement on Mandmove/Siderol 1
\end{abstract}

Existing Acres

$\frac{\text { Surface Water }}{21.2} \frac{\text { Groundwater }}{8.7} \quad \frac{\text { All }}{11.5} \quad \frac{\text { Surface Water }}{24.2} \frac{\text { Groundwar }}{11.7} \frac{\text { AII }}{17.5}$

21.1

21.2

13.6

New Acres

$11.7 \quad 17.5$

$9.7 \quad 14.0$

10.3

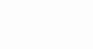

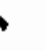


REFERENCES

Andreas, J. C. 1982. "Energy-Efficient Motors." New York: Marcel Dekker, Inc.

Bonneville Power Administration (BPA). 1985. Bonneville Power Administration Forecasts of Electricity Consumption in the Pacific Northwest. D0E-BP529, Bonneville Power Administration. Portland, Oregon.

GTenn, M. V. 1983. "Energy Efficient Electric Motors," a paper given at a symposium entitled Energy-Efficient Electric Motors: Their Control and Application, 1983, Bonneville Power Administration, Portland, Oregon.

Hamrick, J. T. 1980. Redesign of Turbine Pump Impeller and Diffuser Using Hydrodynamic Design Techniques. Aerospace Research Corporation, Roanoke, Virginia.

Hane, G. J., J. C. King, S. A. Smith, and R. L. Watts. 1983. Assessment of Electric Power Conservation and Supply Resources in the Pacific Northwest, Volume III-Industrial Conservation. Battelle Pacific Northwest Laboratories, Richland Washington. Prepared for the Pacific Northwest Electric Power and Conservation Planning Council, Portland, Oregon.

Hansen, H. J. and M. N. Shearer. 1983. Efficiency Performance Criteria for Irrigation Systems. Oregon State University, Corvallis, Oregon.

Harrer, B. J., J. W. Tawil, A. J. Lyke, L. A. Nieves, E. S. Edin and B. M. Bailey, 1987. Empirical Impact Evaluation of the Energy Savings Resulting from BPA's Stage II Irrigation System Retrofit Program. PNL-6160, Pacific Northwest Laboratory, Richland, Washington.

Harrer, B. J., J. W. Johnston, and L. J. Davis. 1986a. A Stratified Random Sampling Plan for an Irrigation Customer Telephone Survey. PNL-5866. Pacific Northwest Laboratory, Richland, Washington.

Harrer, B. J., et al. 1986b. Irrigation Customer Survey Procedures and Analysis. PNL-6181, Pacific Northwest Laboratory, Richland, Washington.

Harrer, B. J., A. J. Lezberg, and G. L. Wilfert. 1985. An Integrated Assessment of Conservation Opportunities in the Irrigated Agriculture Sector of the Pacific Northwest Region. PNL-5406, Pacific Northwest Laboratory, Richland, Washington.

Helweg, 0. J., V. H. Scott, and J. C. Scalmamine. 1981. A Manual on Improving Groundwater Well and Pump Efficiency. University of California, Davis, California.

Helweg, 0. J. and V. H. Scott. 1980. Final Report: Groundwater Irrigation Supply System Optimization. University of California, Davis, California. 
Highsmith, R. M. and A. J. Kimerling. 1979. Atlas of the Pacific Northwest. Oregon State University Press, Corvallis, Oregon.

Hunt, Robert E., Frank Seabury, and Philip F. Valence. 1976. Energy Efficiency and Electric Motors. PB-259 129. Arthur D. Little, Inc. Cambridge Massachusetts. Prepared for the Federal Energy Administration, Office of Industrial Program.

Keinz, J. R, and R. L. Houlton. 1981. "NEMA Normal Efficiency - What is It and Why?" IEEE Transactions, September/0ctober 1981, Volume IA-17, Number 5, pp. 454-457.

Moe, R. J., B. J. Harrer, M. A. Kellogg, A. J. Lyke, K. L. Imhoff, and Z. J. Fisher. 1986. The Electric Energy Savings from New Technologies. Pacific Northwest Laboratory, Richland Washington. PNL-5665 Rev. 1 . Prepared for the U.S. Department of Energy, Washington, DC.

Northwest Power Planning Council (NPPC). 1986. Northwest Conservation and Electric Power Plan, Volume 1. Northwest Power Planning Council, Portland, Oregon.

Pacific Northwest River Basins Commission (PNRBC). 1969. The Region. Pacific Northwest River Basins Commission, Vancouver, Washington.

Potato Grower of Idaho. 1982. "Is Your Pump Efficient?" 2(2). February 1982. Idaho Falls, Idaho.

University of California. 1978. "Pumping Energy Requirements for Irrigation in California," Special Publication 3215, 1978, University of California, Division of Agricultural Sciences. 
APPENDIX A

LOW/HIGH PUMPING PLANT EFFICIENCIES 
APPENDIX A

\section{LOW/HIGH PUMPING PLANT EFFICIENCIES}

This appendix identifies those irrigation pumping plants that operate at plant efficiencies significantly different from the central tendency for a particular horespower category of pumping plants. These plants were identified as having either a significantly lower or higher plant efficiency. Significancy is based on a statistical analysis of plant efficiency data. With a group of pumping plants, those plants with efficiencies greater or less than one standard deviation from the arithmetic mean for the group were considered "significantly different." Approximately $58 \%$ of all plants will fall within one standard deviation, leaving approximately $32 \%$ of the plants to be classified as "significantly different." The actual value of plant efficiency at the 1.0 standard deviation point is dependent on the variability of the data. Of the plants that are classified as "significantly different," three classes of significance are noted; those that fall within 1.0 and 1.5 standard deviation, those that fall within 1.5 and 2.0 standard deviation, and those that fall beyond 2.0 standard deviations. Statistically, approximately $5 \%$ of the plants will have efficiencies that fall beyond the 2.0 standard deviation value.

Irrigation pumping plants were grouped into five horsepower categories (0 to 25, 26 to 50, 51 to 100,101 to 150, and 151 to 250). Because the central tendencies (arithmetic mean) for each group of pumping plants varied slightly, each group of plants were independently analyzed. The following tables identify those plants that are considered to have plant efficiencies significantly different from the central tendency for their groups. Table A.l shows the range of pumping plant efficiencies that fell within each defined class of "significantly different efficiencies." The remaining tables identify specific plants that fall within each class of "significantly different efficiencies." 
TABLE A.1. Definitions of "Significantly Different" Pumping Plant Efficiencies for Various Pump Size Categories

Pumping Plant Efficiency

\begin{tabular}{|c|c|c|c|c|}
\hline \multirow[b]{2}{*}{ Horsepower } & \\
\hline & $\bar{x} \mp(1.0$ to $1.5 \sigma)(\mathrm{a})$ & $\overline{\bar{x}} \mp(1.5 \mathrm{t}$ & to 2.00$)$ & $\bar{x} \mp(>2.000)$ \\
\hline 0 to 25 & $\begin{array}{l}+66 \text { to } 73 \\
-34 \text { to } 41\end{array}$ & $\begin{array}{l}73 \mathrm{t} \\
28 \mathrm{t}\end{array}$ & $\begin{array}{l}\text { to } 79 \\
\text { to } 34\end{array}$ & $\begin{array}{l}79 \text { to } 86 \\
<28\end{array}$ \\
\hline 26 to 50 & $\begin{array}{l}+69 \text { to } 75 \\
-40 \text { to } 46\end{array}$ & $\begin{array}{l}75 \mathrm{t} \\
34 \mathrm{t}\end{array}$ & $\begin{array}{l}\text { to } 80 \\
\text { to } 40\end{array}$ & $\begin{array}{l}80 \text { to } 86 \\
<34\end{array}$ \\
\hline 51 to 100 & $\begin{array}{l}+72 \text { to } 78 \\
-45 \text { to } 50\end{array}$ & $\begin{array}{l}78 \mathrm{t} \\
40 \mathrm{t}\end{array}$ & $\begin{array}{l}\text { to } 83 \\
\text { to } 45\end{array}$ & $\begin{array}{l}83 \text { to } 86 \\
<40\end{array}$ \\
\hline 101 to 150 & $\begin{array}{l}+75 \text { to } 82 \\
-42 \text { to } 49\end{array}$ & $\begin{array}{l}82 t \\
36 t\end{array}$ & $\begin{array}{l}\text { to } 86 \\
\text { to } 42\end{array}$ & $\begin{array}{l}-- \\
<36\end{array}$ \\
\hline 151 to 250 & $\begin{array}{l}+74 \text { to } 81 \\
-42 \text { to } 49\end{array}$ & $\begin{array}{ll}81 \mathrm{t} \\
36 \mathrm{t}\end{array}$ & $\begin{array}{l}\text { to } 86 \\
\text { to } 42\end{array}$ & -- \\
\hline 251 to 500 & $\begin{array}{l}+72 \text { to } 79 \\
-37 \text { to } 44\end{array}$ & $\begin{array}{l}79 t \\
30 t\end{array}$ & $\begin{array}{l}\text { to } 86 \\
\text { to } 37\end{array}$ & $\begin{array}{l}-- \\
<30\end{array}$ \\
\hline
\end{tabular}

(a) $\bar{x} \mp(1.0$ to $1.5 \sigma)$ is interpreted as the mean pumping plant efficiency range for a horsepower size category that is equal to plus or minus 1.0 to 1.5 standard errors about the mean. 
TABLE A.2. Irrigation Pumping Plants with Horsepower Between 0 and 25 Horsepower; Plants with Operation Efficiencies Below 2.0 Standard Deviations or More Below the Mean Efficiency

\begin{tabular}{|c|c|c|c|}
\hline Horsepower & $\begin{array}{c}\text { Plant } \\
\text { Effic. } \\
<28 \\
\end{array}$ & $\begin{array}{l}\text { Plant Identification by } \\
\text { Utility or Code Number }\end{array}$ & Comments \\
\hline \multirow{18}{*}{$\begin{array}{l}0 \text { to } 25 \\
\text { prob }\end{array}$} & 13 & Ravalli & B-Elec Hazard/wiring \\
\hline & 14 & Ravalli & B-Main Valve Present \\
\hline & 15 & SREC & $\mathrm{B}-1$ \\
\hline & 16 & Rava $11 i$ & B-Main Valve Present \\
\hline & 17 & Ravalli & B-Main Valve Present \\
\hline & 19 & Ravalli & $\begin{array}{l}\text { B-Leaks, Main Valve } \\
\text { Present }\end{array}$ \\
\hline & 19 & Ravalli & $\begin{array}{l}\text { B-Leaks, Main Valve } \\
\text { Present }\end{array}$ \\
\hline & $\begin{array}{l}20 \\
21\end{array}$ & Raval1i & $\begin{array}{l}\text { B-Shaded, Leaks } \\
0\end{array}$ \\
\hline & 21 & & 0 \\
\hline & 21 & Columbia REA & R \\
\hline & 21 & Ravalli & B-Main Valve Present \\
\hline & $\begin{array}{l}23 \\
24\end{array}$ & $\begin{array}{l}\text { Ferry Co. } \\
\text { Columbia REA }\end{array}$ & $\begin{array}{l}\text { B-Main Valve Present } \\
B\end{array}$ \\
\hline & 25 & & 0 \\
\hline & 25 & Ravali i & $\begin{array}{l}\text { B-Leaks, Main Valve } \\
\text { Present }\end{array}$ \\
\hline & 26 & & 0 \\
\hline & 26 & Columbia REA & B \\
\hline & 27 & & 0 \\
\hline & 27 & Ravalli & $\begin{array}{l}\text { B-Leaks, Main Valve } \\
\text { Present }\end{array}$ \\
\hline
\end{tabular}


TABLE A.3. Irrigation Pumping Plants with Horsepower Between 0 and 25 Horsepower; Plants with Operation Efficiencies from 1.5 to 2.0 Standard Deviations Below the Arithmetic Mean

\begin{tabular}{|c|c|c|c|}
\hline Horsepower & $\begin{array}{r}\text { Plant } \\
\text { Effic. } \\
28 \text { to } 34 \\
\end{array}$ & $\begin{array}{l}\text { Plant Identification by } \\
\text { Utility or Code Numbers }\end{array}$ & Comments \\
\hline 0 to 25 & $\begin{array}{l}30 \\
30 \\
30 \\
30 \\
\\
31 \\
\\
31 \\
\\
32 \\
32 \\
32 \\
33 \\
33 \\
33 \\
34\end{array}$ & $\begin{array}{l}\text { Ravalli } \\
\text { Columbia Basin } \\
\text { Franklin Co. } \\
\text { Ravalli }\end{array}$ & $\begin{array}{l}0 \\
0 \\
0 \\
\text { B-Leaks, Main Valve } \\
\text { B-Leaks, Main Valve } \\
\text { Present } \\
\text { B-Cracked, Broken/ } \\
\text { vibration } \\
0 \\
\text { B-Main Valve Present } \\
\text { B } \\
0 \\
\text { B } \\
\text { B-Leaks } \\
0\end{array}$ \\
\hline
\end{tabular}


TABLE A.4. Irrigation Pumping Plants with Horsepower Between 0 and 25 Horsepower; Plants with Operation Efficiencies from 1.0 to 1.5 Standard Deviations Below the Arithmetic Mean

\begin{tabular}{|c|c|c|c|}
\hline Horsepower & $\begin{array}{r}\text { Plant } \\
\text { Effic. } \\
28 \text { to } 34 \\
\end{array}$ & $\begin{array}{l}\text { Plant Identification by } \\
\text { Utility or Code Number }\end{array}$ & Comments \\
\hline \multirow[t]{30}{*}{0 to 25} & 35 & Ravalli & B-Main Valve Present \\
\hline & 35 & Ravali & $B-1$ \\
\hline & 35 & Ravalli & B \\
\hline & 36 & & 0 \\
\hline & 36 & Franklin Co. & B \\
\hline & 36 & Ferry Co. & $B-1$ \\
\hline & 37 & & 0 \\
\hline & 37 & & 0 \\
\hline & 37 & & 0 \\
\hline & 37 & & 0 \\
\hline & 37 & Central Elec. & B \\
\hline & 38 & & 0 \\
\hline & 38 & & 0 \\
\hline & 38 & & 0 \\
\hline & 38 & Ravalli & B-Main Valve Present \\
\hline & 38 & Frankitin Co. & B \\
\hline & 38 & Ferry Co. & $\begin{array}{l}\text { B-Leaks, Main Valve } \\
\text { Present }\end{array}$ \\
\hline & 39 & & 0 \\
\hline & 39 & Ferry Co. & B-Leaks, Main Valve \\
\hline & 39 & Ravalli & $\begin{array}{l}\text { Present } \\
\text { B-Leaks, Main Valve }\end{array}$ \\
\hline & & & Present \\
\hline & 39 & Vigilante & B-Leaks, Main Valve \\
\hline & 40 & & $\begin{array}{l}\text { Present } \\
0\end{array}$ \\
\hline & 40 & & 0 \\
\hline & 40 & & 0 \\
\hline & 40 & Ferry Co. & B-Main Valve Present \\
\hline & 40 & Ferry Co. & $\begin{array}{l}\text { B-Leaks, Main Valve } \\
\text { Present }\end{array}$ \\
\hline & 41 & Ravalli & B-Leaks, Main Valve \\
\hline & 41 & Ferry Co. & $\begin{array}{l}\text { Present } \\
\text { B-Main Valve Present }\end{array}$ \\
\hline & 41 & Central Elec. & B \\
\hline
\end{tabular}


TABLE A.5. Irrigation Pumping Plants with Horsepower Between 0 and 25 Horsepower; Plants with Operation Efficiencies from 1.0 to 1.5 Standard Deviations Above the Arithmetic Mean

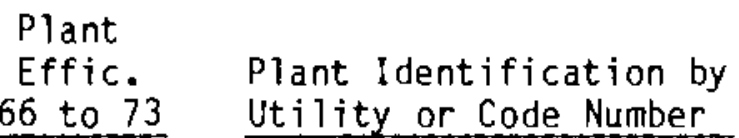

Horsepower 66 to 73 Utility or Code Number

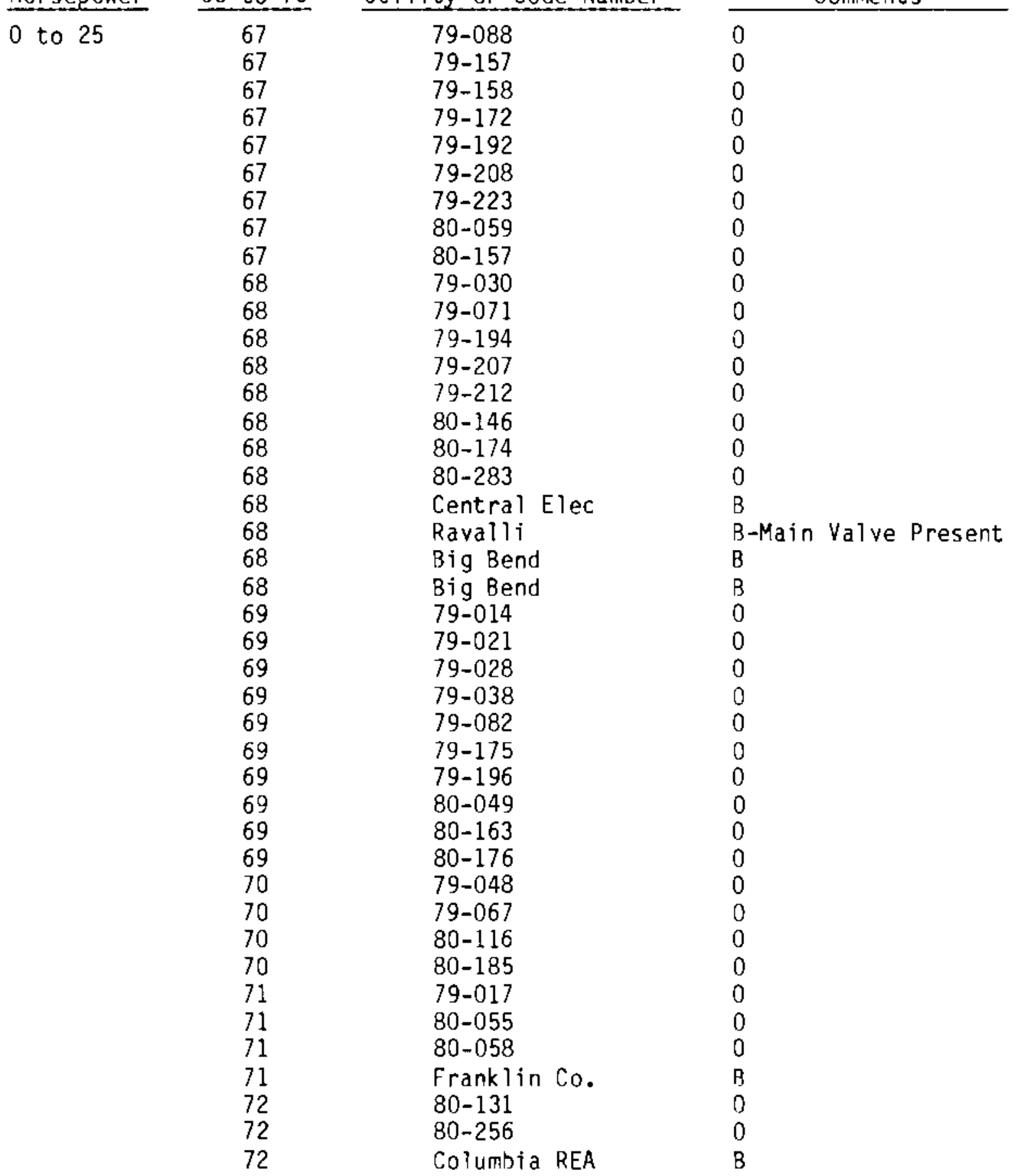


TABLE A.5. (contd)

\begin{tabular}{|c|c|c|c|}
\hline Horsepower & $\begin{array}{l}\text { Plant } \\
\text { Effic. } \\
66 \text { to } 73 \\
\end{array}$ & $\begin{array}{l}\text { Plant Ident ification by } \\
\text { Utility or Code Number }\end{array}$ & Comments \\
\hline & $\begin{array}{l}73 \\
73 \\
73 \\
73\end{array}$ & $\begin{array}{l}79-226 \\
80-132 \\
80-211 \\
\text { Big Bend }\end{array}$ & $\begin{array}{l}0 \\
0 \\
0 \\
B\end{array}$ \\
\hline
\end{tabular}

TABLE A.6. Irrigation Pumping Plants with Horsepower Between 0 and 25 Horsepower; Plants with Operation Efficiencies from 1.5 to 2.0 Standard Deviations Above the Arithmetic Mean

\begin{tabular}{|c|c|c|c|}
\hline Horsepower & $\begin{array}{l}\text { Plant } \\
\text { Effic. } \\
73 \text { to } 79 \\
\end{array}$ & Plant Identification & Comments \\
\hline 0 to 25 & $\begin{array}{l}73 \\
73 \\
73 \\
73 \\
74 \\
75 \\
76 \\
76 \\
76 \\
78\end{array}$ & $\begin{array}{l}79-226 \\
80-132 \\
80-211 \\
\text { Big Bend } \\
79-029 \\
79-110 \\
79-150 \\
80-020 \\
80-160 \\
\text { Big Bend }\end{array}$ & $\begin{array}{l}0 \\
0 \\
0 \\
B \\
0 \\
0 \\
0 \\
0 \\
0 \\
B\end{array}$ \\
\hline
\end{tabular}

TABLE A.7. Irrigation Pumping Plants with Horsepower Between 0 and 25 Horsepower; Plants with Operation Efficiencies 2.0 Standard Deviations or More Above the Mean

\begin{tabular}{|c|c|c|c|}
\hline $\begin{array}{c}\text { Plant } \\
\text { Effic. } \\
\text { Horsepower } \\
\end{array}$ & 79 to 83 & Plant Identification & Comments \\
\hline 0 to 25 & $\begin{array}{l}79 \\
80 \\
80 \\
81 \\
81 \\
81 \\
82 \\
83 \\
83 \\
83\end{array}$ & $\begin{array}{l}\text { 80-212 } \\
\text { Big Bend } \\
\text { Big Bend } \\
\text { Big Bend } \\
\text { Big Bend } \\
\text { Big Bend } \\
\text { Big Bend } \\
\text { Lincoln } \\
\text { Franklin Co. } \\
\text { Big Bend }\end{array}$ & $\begin{array}{l}0 \\
B \\
B \\
B \\
B \\
B \\
B \\
B \\
B- \\
B \\
B\end{array}$ \\
\hline
\end{tabular}


TABLE A.8. Irrigation Pumping Plants with Horsepower Between 26 and 50 Horsepower; Plants with Operation Efficiencies 2.0 Standard Deviations or More Below the Mean

\begin{tabular}{|c|c|c|c|}
\hline Horsepower & $\begin{array}{l}\text { Plant } \\
\text { Effic. } \\
<34\end{array}$ & Plant I dentification & Comments \\
\hline \multirow[t]{8}{*}{26 to 50} & 9 & Vigilante & $\begin{array}{l}\text { B-Leaks, Main Valve } \\
\text { Present }\end{array}$ \\
\hline & 14 & $79-024$ & 0 \\
\hline & $\begin{array}{l}23 \\
25\end{array}$ & $\begin{array}{l}\text { Vigilante } \\
\text { Lost River }\end{array}$ & $\begin{array}{l}\text { B-Main Valve Present } \\
\text { B-1 }\end{array}$ \\
\hline & $\begin{array}{l}27 \\
28\end{array}$ & $\begin{array}{l}\text { Vigilante } \\
\text { Columbia REA }\end{array}$ & $\begin{array}{l}\text { B-Main Valve Present } \\
B\end{array}$ \\
\hline & 28 & Vigilante & B-Main Valve Present \\
\hline & 30 & Vigilante & B-Main Valve Present \\
\hline & 31 & Ravalli & $\begin{array}{l}\text { B-Leaks, Main Valve } \\
\text { Present }\end{array}$ \\
\hline & 32 & Columbia Basin & $\mathrm{B}$ \\
\hline
\end{tabular}

TABLE A.9. Irrigation Pumping Plants with Horsepower Between 26 and 50 Horsepower; Plants with Operation Efficiencies from 1.5 to 2.0 Standard Deviations Below the Arithmetic Mean

\begin{tabular}{|c|c|c|c|}
\hline Horsepower & $\begin{array}{l}\text { Plant } \\
\text { Effic. } \\
79 \text { to } 83\end{array}$ & Plant Identification & Comments. \\
\hline 26 to 50 & $\begin{array}{l}34 \\
34 \\
35 \\
36 \\
37 \\
37 \\
38 \\
39 \\
39 \\
39 \\
39\end{array}$ & $\begin{array}{l}\text { Ravalli } \\
\text { Benton } \\
\text { Big Bend } \\
\text { Big Bend } \\
79-148 \\
\text { Benton } \\
\text { CoTumbia REA } \\
79-174 \\
79-146 \\
80-062 \\
\text { Big Bend }\end{array}$ & $\begin{array}{l}\text { B-Main Valve Present } \\
\text { B } \\
B \\
B \\
0 \\
B \\
B \\
0 \\
0 \\
0 \\
B\end{array}$ \\
\hline
\end{tabular}


TABLE A.10. Irrigation Pumping Plants with Horsepower Between 26 and 50 Horsepower; Plants with Operation Efficiencies from 1.0 to 1.5 Standard Deviations Below the Arithmetic Mean

\begin{tabular}{|c|c|c|c|}
\hline Horsepower & $\begin{array}{l}\text { Plant } \\
\text { Effic. } \\
40 \text { to } 46 \\
\end{array}$ & Plant Identification & Comments \\
\hline \multirow{20}{*}{26 to 50} & 40 & $80-036$ & D \\
\hline & 41 & $79-095$ & 0 \\
\hline & 41 & $79-243$ & 0 \\
\hline & 41 & $80-097$ & 0 \\
\hline & 41 & Vịilante & $B-1$ \\
\hline & 41 & Ravalli & B-Main Valve Present \\
\hline & 42 & 79.023 & 0 \\
\hline & 42 & $79-047$ & 0 \\
\hline & 42 & Linclon & B-Main Valve Present \\
\hline & 43 & $79-059$ & 0 \\
\hline & 43 & $80-151$ & 0 \\
\hline & 43 & Big Bend & B \\
\hline & 43 & SREC & $B-1$ \\
\hline & 44 & $79-044$ & 0 \\
\hline & 44 & $79-053$ & 0 \\
\hline & 44 & Grant Co. & $B-1$ \\
\hline & 44 & Big Bend & B \\
\hline & 44 & Big Bend & B \\
\hline & 45 & $79-113$ & 0 \\
\hline & 45 & Big Bend & B \\
\hline
\end{tabular}


TABLE A.11. Irrigation Pumping Plants with Horsepower Between 26 and 50 Horsepower; Plants with Operation Efficiencies from 1.0 to 1.5 Standard Deviations Above the Arithmetic Mean

\begin{tabular}{|c|c|c|c|}
\hline Horsepower & $\begin{array}{l}\text { Plant } \\
\text { Effic. } \\
69 \text { to } 75 \\
\end{array}$ & Plant Identification & Comments \\
\hline 26 to 50 & $\begin{array}{l}69 \\
69 \\
69 \\
69 \\
69 \\
69 \\
69 \\
69 \\
69 \\
69 \\
69 \\
69 \\
69 \\
70 \\
70 \\
70 \\
70 \\
70 \\
70 \\
70 \\
70 \\
70 \\
70 \\
70 \\
70\end{array}$ & $\begin{array}{l}79-012 \\
79-019 \\
79-034 \\
79-209 \\
79-234 \\
80-203 \\
\text { Vigilante } \\
\text { Columbia Basin } \\
\text { Grant County } \\
\text { Central Elec } \\
\text { Lincoln } \\
\text { Lincoln } \\
\text { Big Bend } \\
79-215 \\
80-034 \\
80-126 \\
\text { Columbia REA } \\
\text { Columbia REA } \\
\text { Big Bend } \\
\text { Central Elec } \\
\text { Big Bend } \\
\text { SREC } \\
\text { Central Elec } \\
\text { Franklin Co. } \\
\text { Lincoln } \\
\text { Lincoln } \\
\text { Big Bend } \\
79-006 \\
79-225 \\
80-193 \\
80-266 \\
\text { Benton } \\
\text { Big Bend } \\
\text { Franklin Co } \\
79-155 \\
79-007 \\
79-195 \\
80-268 \\
\text { Big Bend } \\
\text { Central Elec } \\
80-235 \\
\text { Big Bend } \\
\text { Bis } \\
\text { Bing }\end{array}$ & 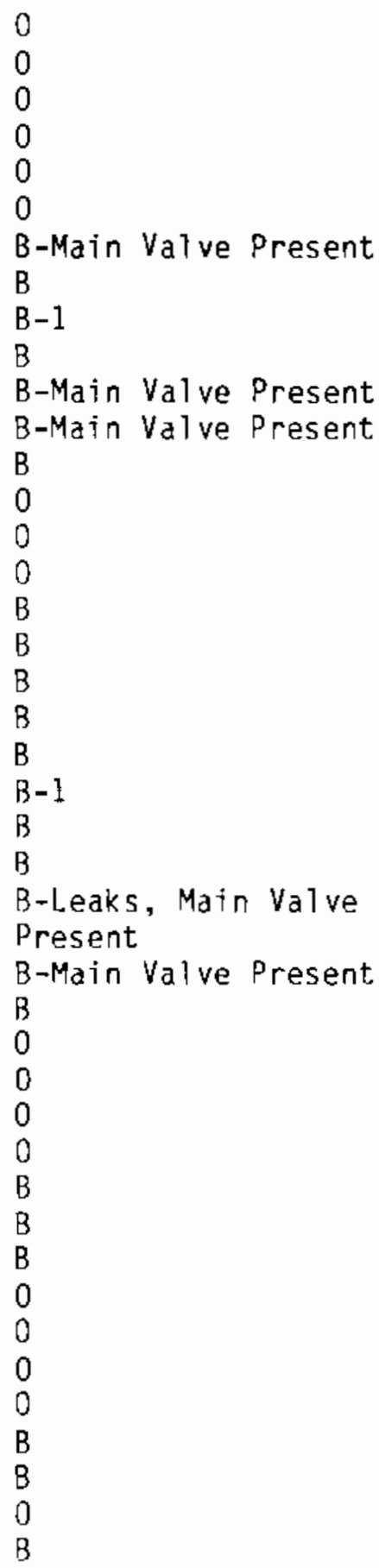 \\
\hline
\end{tabular}


TABLE A.12. Irrigation Pumping Plants with Horsepower Between 26 and 50 Horsepower; Plants with Operation Efficiencies from

1.5 to 2.0 Standard Deviations Above the Arithmetic Mean

$$
\text { Plant }
$$

Horsepower 75 to $80 \quad$ Plant Identification

26 to 50

75
75
76
76
76
77
77
77
78
78
78
78

$80-119$
$80-271$
Vigilante
Big Bend
Grant Co.
$79-164$
$79-165$
$80-218$
$80-181$
Big Bend
Ferry Co.
M. Gallinger

\begin{tabular}{l} 
Comments \\
\hline 0 \\
0 \\
B-Leaks \\
B \\
B-1 \\
0 \\
0 \\
0 \\
0 \\
B \\
B-Main Val ve Present \\
Big BendB
\end{tabular}

TABLE A.13. Irrigation Pumping Plants with Horsepower Between 26 and 50 Horsepower; Plants with Operation Efficiencies

\begin{tabular}{|c|c|c|c|}
\hline Horsepower & $\begin{array}{l}\text { Plant } \\
\text { Effic. } \\
80 \text { to } 86\end{array}$ & Plant Identification & Comments \\
\hline $26-50$ & $\begin{array}{l}81 \\
81 \\
81 \\
82 \\
83 \\
83 \\
83\end{array}$ & $\begin{array}{l}\text { Big Bend } \\
\text { Big Bend } \\
\text { Big Bend } \\
\text { Big Bend } \\
\text { Lincoln } \\
\text { Franklin Co. } \\
\text { Big Bend }\end{array}$ & $\begin{array}{l}B \\
B \\
B \\
B \\
B-1 \\
B \\
B\end{array}$ \\
\hline
\end{tabular}

2.0 Standard Deviations or More Above the Mean 
TABLE A.14. Irrigation Pumping Plants with Horsepower Between 51 and 100 Horsepower; Plants with Operation Efficiencies

2.0 Standard Deviations or More Below the Mean

\begin{tabular}{|c|c|c|c|}
\hline Horsepower & $\begin{array}{c}\text { Plant } \\
\text { Effic. } \\
<40 \\
\end{array}$ & Plant Identification & Comments \\
\hline 51 to 100 & $\begin{array}{l}32 \\
34 \\
34 \\
35 \\
35 \\
35 \\
36 \\
38 \\
38 \\
39 \\
39\end{array}$ & $\begin{array}{l}\text { Columbia REA } \\
80-262 \\
\text { Vigilante } \\
79-118 \\
\text { Columbia REA } \\
\text { Vigilante } \\
80-028 \\
79-119 \\
80-236 \\
79-124 \\
\text { Vigilante }\end{array}$ & $\begin{array}{l}\text { B } \\
0 \\
\text { B-Main Valve Present } \\
0 \\
B \\
B-1 \\
0 \\
0 \\
0 \\
0 \\
\text { B-Leaks, Main Valve Present }\end{array}$ \\
\hline
\end{tabular}

TABLE A.15. Irrigation Pumping Plants with Horsepower Between 51 and 100 Horsepower; Plants with Operation Efficiencies from 1.5 to 2.0 Standard Deviations Below the Arithmetic Mean

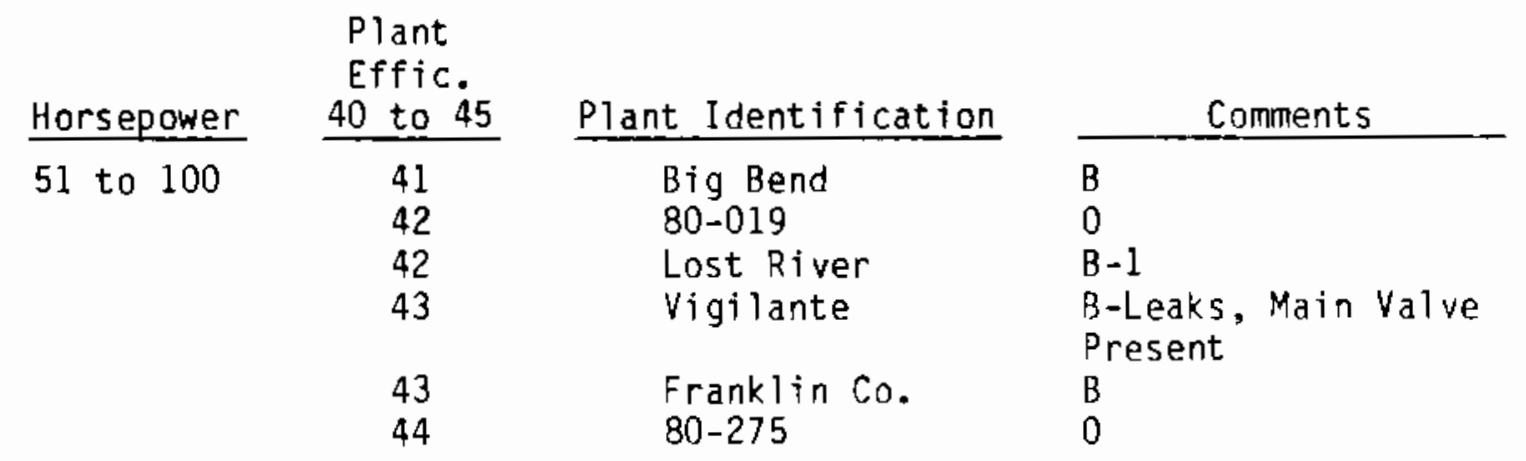


TABLE A.16. Irrigation Pumping Plants with Horsepower Between 51 and 100 Horsepower; Plants with Operation Efficiencies from

1.0 to 1.5 Standard Deviations Below the Arithmetic Mean

\begin{tabular}{|c|c|c|c|}
\hline Horsepower & $\begin{array}{l}\text { Plant } \\
\text { Effic. } \\
45 \text { to } 50 \\
\end{array}$ & Plant Identification & Comments \\
\hline \multirow[t]{15}{*}{51 to 100} & 45 & Big Bend & B \\
\hline & 45 & Vigilante & $\begin{array}{l}\text { B-Leaks, Main Valve } \\
\text { Present }\end{array}$ \\
\hline & 47 & Vigilante & B-Main Valve Present \\
\hline & 48 & $80-004$ & 0 \\
\hline & 48 & $80-040$ & 0 \\
\hline & 49 & $80-189$ & 0 \\
\hline & 49 & $80-258$ & 0 \\
\hline & 49 & $80-274$ & 0 \\
\hline & 49 & Big Bend & B \\
\hline & 49 & Big Bend & B \\
\hline & 50 & $80-109$ & 0 \\
\hline & 50 & $80-234$ & 0 \\
\hline & 50 & Lincoln & $B-1$ \\
\hline & 50 & Vigilante & B-Leaks, Main Valve \\
\hline & 50 & Columbia Basin & $\begin{array}{l}\text { Present } \\
B\end{array}$ \\
\hline
\end{tabular}


TABLE A.17. Irrigation Pumping Plants with Horsepower Between 51 and 100 Horsepower; Plants with Operation Efficiencies from 1.0 to 1.5 Standard Deviations Above the Arithmetic Mean Plant Effic.

Horsepower 72 to 78 Plant Identification

51 to 100

73
73
73
73
73
73
73
74
74
74
74
75
75
75
75
75
75
75
76
76
76
76
77
77
77
77

$79-174$

80-044

$80-133$

$80-253$

Big Bend

Franklin Co.

Columbia Basin

80-021

80-252

Midstate

Big Bend

80-003

80-250

Big Bend

Lincoln

Lincoln

Vigilante

Franklin Co.

Big Bend

Big Bend

Big Bend

Big Bend

79-087

80-223

Columbia Basin

Grant Co.
Comments

0

0

0

0

B

B

B

0

0

B-1

$B$

0

0

B

$B-1$

$B-1$

B-Main Valve Present

$\mathrm{B}$

B

B

B

B

0

0

B

$\mathrm{B}-1$

TABLE A.18. Irrigation Pumping Plants with Horsepower Between 51 and 100 Horsepower; Plants with Operation Efficiencies from 1.5 to 2.0 Standard Deviations Above the Arithmetic Mean

\begin{tabular}{|c|c|c|c|}
\hline Horsepower & $\begin{array}{l}\text { Plant } \\
\text { Effic. } \\
78 \text { to } 83 \\
\end{array}$ & Plant Identification & Comments \\
\hline 51 to 100 & $\begin{array}{l}78 \\
78 \\
78 \\
79 \\
81 \\
83 \\
83\end{array}$ & $\begin{array}{l}\text { Lincoln } \\
\text { Franklin Co. } \\
\text { Big Bend } \\
\text { Franklin Co. } \\
\text { Big Bend } \\
\text { Lincoln } \\
\text { Big Bend }\end{array}$ & $\begin{array}{l}B-1 \\
B \\
B \\
B \\
B \\
B-1 \\
B\end{array}$ \\
\hline
\end{tabular}


TABLE A.19. Irrigation Pumping Plants with Horsepower Between 51 and 100 Horsepower; Plants with Operation Efficiencies

2.0 Standard Oeviations or More Above the Mean

Plant

Effic.

Horsepower 83 to 86 Plant Identification

Cominents

\section{A. 15}


TABLE A.20. Irrigation Pumping Plants with Horsepower Between 101 and 150 Horsepower Plants with Operation Efficiencies

2.0 Standard Deviations or More Below the Mean

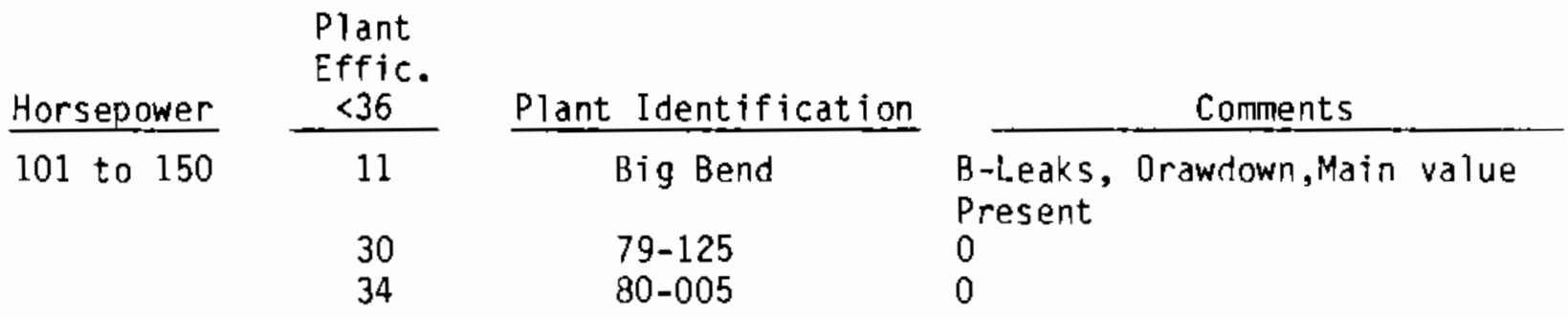

TABLE A.21. Irrigation Pumping Plants with Horsepower Between 101 and 150 Horsepower; Plants with Operation Efficiencies from 1.5 to 2.0 Standard Deviations Below the Arithmetic Mean

\begin{tabular}{|c|c|c|c|}
\hline Horsepower & $\begin{array}{c}\text { Plant } \\
\text { Effic. } \\
36 \text { to } 42 \\
\end{array}$ & Plant Identification & Comments \\
\hline 101 to 150 & $\begin{array}{l}37 \\
38 \\
39 \\
40\end{array}$ & $\begin{array}{l}\text { Big Bend } \\
80-024 \\
\text { Benton } \\
\text { Lincoln }\end{array}$ & $\begin{array}{l}B \\
0 \\
B \\
B-M a i n V a l v e\end{array}$ \\
\hline
\end{tabular}

TABLE A.22. Irrigation Pumping Plants with Horsepower Between 101 and 150 Horsepower; Plants with Operation Efficiencies from 1.0 to 1.5 Standard Deviations Below the Arithmetic Mean

\begin{tabular}{|c|c|c|c|}
\hline Horsepower & $\begin{array}{r}\text { Plant } \\
\text { Effic. } \\
42 \text { to } 49 \\
\end{array}$ & Plant Identification & Comments \\
\hline 101 to 150 & $\begin{array}{l}42 \\
44 \\
46 \\
48\end{array}$ & $\begin{array}{l}80-014 \\
\text { Big Bend } \\
\text { Vigilante } \\
\text { Lincoln }\end{array}$ & $\begin{array}{l}0 \\
B \\
B-M a i n \text { Valve Present } \\
B-1\end{array}$ \\
\hline
\end{tabular}


TABLE A.23. Irrigation Pumping Plants with Horsepower Between 101 and

150 Horsepower; Plants with Operation Efficiencies from

1.0 to 1.5 Standard Deviations Above the Arithmetic Mean

\begin{tabular}{|c|c|c|c|}
\hline Horsepower & $\begin{array}{r}\text { Plant } \\
\text { Effic. } \\
75 \text { to } 82 \\
\end{array}$ & Plant Identification & Comments \\
\hline 101 to 150 & $\begin{array}{l}76 \\
76\end{array}$ & $\begin{array}{l}\text { Big Bend } \\
\text { Lincoln }\end{array}$ & $\begin{array}{l}\text { B } \\
\text { B-Leaks, Main Valve } \\
\text { Present }\end{array}$ \\
\hline & $\begin{array}{l}76 \\
77 \\
77 \\
77 \\
77 \\
78 \\
78 \\
78 \\
79 \\
80 \\
80\end{array}$ & $\begin{array}{l}\text { Franklin } \mathrm{Co} . \\
\text { Franklin } \mathrm{Co} . \\
\text { Franklin } \mathrm{Co} . \\
\text { Big Bend } \\
\text { Midstate } \\
80-026 \\
\text { Vigilante } \\
\text { Franklin Co. } \\
\text { Ferry Co. } \\
\text { Big Bend } \\
\text { Big Bend }\end{array}$ & $\begin{array}{l}\text { B } \\
\text { B } \\
\text { B } \\
\text { B } \\
\text { B-1 } \\
0 \\
\text { B-Main Val ve Present } \\
\text { B } \\
\text { B-1 } \\
\text { B } \\
\text { B }\end{array}$ \\
\hline
\end{tabular}


TABLE A.24. Irrigation Pumping Plants with Horsepower Between 101 and 150 Horsepower; Plants with Operation Efficiencies from 1.5 to 2.0 Standard Deviations Above the Arithmetic Mean

Plant

Effic.

Horsepower 82 to 86 Plant Identification Comments 
TABLE A.25. Irrigation Pumping Plants with Horsepower Between 151 and 250 Horsepower; Plants with Operation Efficiencies 2.0 Standard Deviations or More Below the Mean

\begin{tabular}{|c|c|c|c|}
\hline Horsepower & $\begin{array}{c}\text { Plant } \\
\text { Effic. } \\
<36\end{array}$ & Plant Identification & Comments \\
\hline 151 to 250 & $\begin{array}{l}16 \\
28\end{array}$ & $\begin{array}{l}\text { Lincoln } \\
80-069\end{array}$ & $\begin{array}{l}B \\
0\end{array}$ \\
\hline
\end{tabular}

TABLE A.26. Irrigation Pumping Plants with Horsepower Between 151 and 250 Horsepower; Plants with Operation Efficiencies from 1.5 to 2.0 Standard Deviations Below the Arithmetic Mean

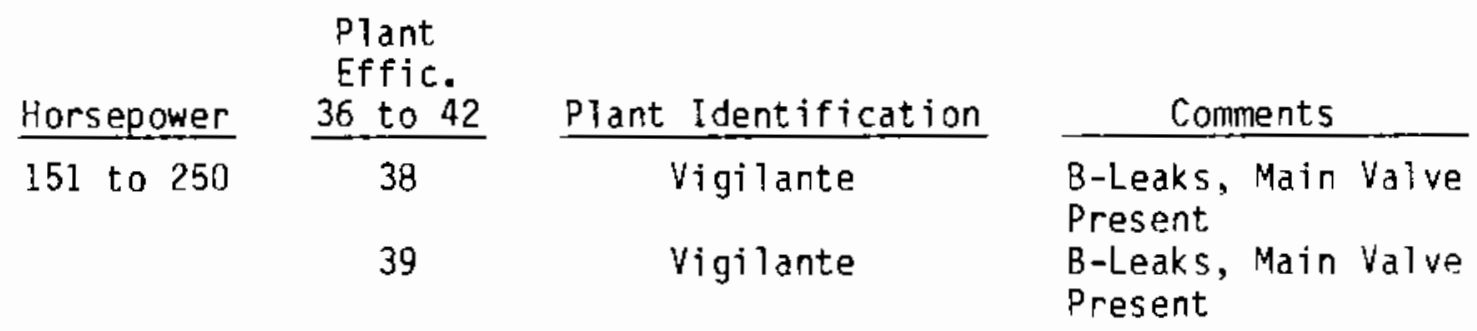

TABLE A.27. Irrigation Pumping Plants with Horsepower Between 151 and 250 Horsepower; Plants with Operation Efficiencies from 1.0 to 1.5 Standard Deviations Below the Arithmetic Mean

\begin{tabular}{|c|c|c|c|}
\hline Horsepower & $\begin{array}{r}\text { Plant } \\
\text { Effic. } \\
42 \text { to } 49 \\
\end{array}$ & Plant Identification & Comments \\
\hline 151 to 250 & $\begin{array}{l}43 \\
44 \\
48\end{array}$ & $\begin{array}{l}\text { Lincoln } \\
\text { Benton } \\
\text { Lincoln }\end{array}$ & $\begin{array}{l}\text { B-Main Valve Present } \\
B \\
\text { B-Main Valve Present }\end{array}$ \\
\hline
\end{tabular}


TABLE A.28. Irrigation Pumping Plants with Horsepower Between 151 and 250 Horsepower; Plants with Operation Efficiencies from 1.0 to 1.5 Standard Deviations Above the Arithmet ic Mean

\begin{tabular}{|c|c|c|c|}
\hline Horsepower & $\begin{array}{c}\text { Plant } \\
\text { Effic. } \\
74 \text { to } 81 \\
\end{array}$ & Plant Identification & Comments \\
\hline 151 to 250 & $\begin{array}{l}75 \\
76 \\
76 \\
76 \\
76 \\
77 \\
78 \\
79\end{array}$ & $\begin{array}{l}\text { Franklin Co. } \\
\text { Franklin } \mathrm{Co} \\
\text { Big Bend } \\
\text { Lincoln } \\
\text { Big Bend } \\
\text { Franklin Co. } \\
\text { Franklin } \mathrm{Co} . \\
\text { Benton }\end{array}$ & $\begin{array}{l}\text { B } \\
\text { B } \\
\text { B } \\
B-1 \\
B \\
B \\
\text { B } \\
\text { B }\end{array}$ \\
\hline
\end{tabular}


TABLE A.29. Irrigation Pumping Plants with Horsepower Between 151 and 250 Horsepower; Plants with Operation Efficiencies from 1.5 to 2.0 Standard Deviations Above the Arithmetic Mean

\begin{tabular}{l} 
Plant \\
Effic. \\
Horsepower \\
81 to 86 \\
\hline
\end{tabular}

151 to 250 
TABLE A.30. Irrigation Pumping Plants with Horsepower Between 251 and 500 Horsepower; Plants with Operation Efficiencies Standard Deviations or More Below the Mean

$\frac{\text { Horsepower }}{251 \text { to } 500} \quad \frac{\begin{array}{c}\text { Plant } \\ \text { Effic. } \\ <30\end{array}}{9} \quad \frac{\text { Plant Identification }}{\text { Big Bend }} \quad \frac{\text { Comments }}{\text { B-Main Valve Present }}$


TABLE A.31. Irrigation Pumping Plants with Horsepower Between 251 and 500 Horsepower; Plants with Operation Efficiencies from 1.5 to 2.0 Standard Deviations Below the Arithmetic Mean

\begin{tabular}{|c|c|c|c|}
\hline Horsepower & $\begin{array}{c}\text { Plant } \\
\text { Effic. } \\
28 \text { to } 34\end{array}$ & Plant Identification & Comments \\
\hline 251 to 500 & $\begin{array}{l}31 \\
34 \\
36\end{array}$ & $\begin{array}{l}\text { Big Bend } \\
\text { Lincoln } \\
\text { Franklin Co. }\end{array}$ & $\begin{array}{l}B \\
B-1 \\
B\end{array}$ \\
\hline
\end{tabular}

TABLE A.32. Irrigation Pumping Plants with Horsepower Between 251 and 500 Horsepower; Plants with Operation Efficiencies from 1.0 to 1.5 Standard Deviations Below the Arithmetic Mean

\begin{tabular}{|c|c|c|c|}
\hline Horsepower & $\begin{array}{l}\text { Plant } \\
\text { Effic. } \\
37 \text { to } 44\end{array}$ & Plant Identification & Comments \\
\hline \multirow[t]{7}{*}{251 to 500} & 38 & $\begin{array}{l}\text { Linclon } \\
\text { Present }\end{array}$ & B-Leaks, Main Valve \\
\hline & 40 & Lincoln & $B-1$ \\
\hline & 40 & Lincoln & B \\
\hline & 41 & Lincoln & B \\
\hline & 43 & Big Bend & 8 \\
\hline & 44 & Franklin Co. & B \\
\hline & 44 & Franklin Co. & $\mathrm{B}$ \\
\hline
\end{tabular}

TABLE A.33. Irrigation Pumping Plants with Horsepower Between 251 and 500 Horsepower; Plants with Operation Efficiencies from 1.0 to 1.5 Standard Deviations Above the Arithmetic Mean

Plant Effic.

\begin{tabular}{|c|c|c|c|}
\hline Horsepower & 72 to 79 & Plant Identification & Comments \\
\hline 251 to 500 & $\begin{array}{l}75 \\
76 \\
77 \\
78\end{array}$ & $\begin{array}{l}\text { Lincoln } \\
\text { Franklin Co. } \\
\text { Lincoln } \\
\text { Lincoln }\end{array}$ & $\begin{array}{l}\text { B-Main Valve Present } \\
B \\
B-1 \\
B-M a i n \text { Valve Present }\end{array}$ \\
\hline
\end{tabular}


TABLE A.34. Irrigation Pumping Plants with Horsepower Between 251 and 500 Horsepower; Plants with Operation Efficiencies from 1.5 to 2.0 Standard Deviation Above the Arithmetic Mean

\begin{tabular}{|c|c|c|c|}
\hline Horsepowe & $\begin{array}{l}\text { Plant } \\
\text { Effic. } \\
79 \text { to } 86\end{array}$ & Plant Identification & Comments \\
\hline 251 to 500 & 79 & Big Bend & $B$ \\
\hline
\end{tabular}


PNL -6194

UC $-95 c$

\section{DISTRIBUTION}

No. of

Copies

OFFSITE

Ken Keating

Bonneville Power Administration

P. 0. Box 3621

Portiand, Oregon 97208

Eric Westman

Bonneville Power Administration

P. 0. Box 3621

Portland, Oregon 97208

Fred Gordon

Bonneville Power Administration

P. 0. Box 3621

Portland, Oregon 97208

Steve Levy

Bonneville Power Administration

P. 0. Box 3621

Portland, Oregon 97208

30

DOE Technical Information

Center

Mary Corrigan Department of Energy

Forrestal Building

1000 Independence Ave., S.W.

Washington, D.C. 20585
No. of

Copies

ONSITE

DOE Richland Operations Office

J. J. Sutey

19 Pacific Northwest Laboratory

B. L. Mohler

G. L. Wilfert

B. J. Harrer (10)

Publishing Coordination MH (2)

Technical Report Files (5) 
